\title{
The use of simultaneous chemical precipitation in modified activated sludge systems exhibiting biological excess phosphate removal Part 6: Modelling of simultaneous chemical-biological $P$ removal - Review of existing models
}

\author{
DW de Haas", MC Wentzel* and GA Ekama \\ Dept. of Civil Engineering, University of Cape Town, Rondebosch 7701, South Africa
}

\begin{abstract}
This paper reviews three published models for simultaneous chemical phosphorus precipitation in activated sludge systems using metal salts. In the first, a chemical equilibrium approach is used, based on observations made from batch and continuous-flow tests, a theoretical formula for metal (e.g. ferric) hydroxy-phosphate and a set of metal phosphate complexes or ion pairs for dissolved orthophosphate (orthoP) species. Apart from applying the precipitation stoichiometry observed in admixture with activated sludge, in this model no interaction between the chemical and biological mechanisms is accounted for and no biological processes are modelled. In the second model, a combined equilibrium-kinetic approach is used to model the chemical and biological processes. The chemical and biological processes become kinetically linked through soluble orthoP as a variable. This model includes biological processes for conventional activated sludge systems, but does not include biological excess P removal processes (BEPR). Apart from this limitation, a potential problem in the combined equilibrium-kinetic approach was identified: The precipitation reactions were modelled based on equilibrium chemistry and assumed to be complete at the start of simulation; precipitate, therefore, could not form dynamically during the ensuing kinetic simulation. Furthermore, the model predictions were very sensitive to the choice of certain key equilibrium (or solubility product) constants. The third approach was to model the precipitation (and dissolution) reactions as kinetic processes within a fully kinetic model for activated systems, including the processes for BEPR. This approach depends on the appropriate selection of rate constants for the forward (precipitation) and reverse (dissolution) reactions. In effect, a number of reactions from equilibrium chemistry are combined and replaced with one "surrogate" reaction having its own apparent equilibrium constant. The kinetic approach offers a number of advantages but is still subject to the limitation that it requires calibration against actual data from activated sludge systems in which simultaneous precipitation is applied. Moreover, interaction between the chemical and biological P removal mechanisms in the model is confined to "competition" for available soluble orthoP. This aspect requires further examination.
\end{abstract}

\section{Introduction}

Mathematical models of modified activated sludge systems incorporating biological nutrient removal (BNR) are well-established (inter alia Dold et al., 1991; Wentzel et al., 1992, Henze et al., 1995). These models serve a useful function as research and design tools, and are also emerging as operator aids by making possible the real-time simulation of full-scale activated sludge plants (Thornberg, 1995). Until very recently, simultaneous chemical precipitation reactions have not been incorporated into models of biological phosphate removal in activated sludge systems. With the prevalence of simultaneous chemical addition to BNR systems, there exists a need for a more comprehensive combined chemical-biological model.

At present, there are three main mathematical (or mechanistic) models for the biological processes in BNR systems: the UCT model (or UCTPHO, in computer program format) (Wentzel et al., 1992); the IAWQ ASM 2 model (Henze et al., 1995; Wentzel and Ekama, 1995) and the Dold model (or "BIOWIN" in computer program format) (Barker and Dold, 1997). These models differ in detail on certain key processes, but do not differ in concept and, if appropriately calibrated, will produce similar results for many

\footnotetext{
\# Formerly Umgeni Water, PO Box 9, Pietermaritzburg 3200.

To whom all correspondence should be addressed.

唺(021) 650-2583; fax (021) 689-7471; e-mail: markw @eng.uct.ac.za Received 14 November 2000.
}

applications. In this study, the objective was not to compare or evaluate the various models in respect of the biological processes, but rather to review the manner in which the chemical P removal processes may be incorporated into the biological model(s). In order to do this, it is first necessary to review the different approaches taken in modelling the chemical $\mathrm{P}$ removal processes.

In the literature there are three main approaches to modelling the chemical $P$ removal processes:

- A chemical equilibrium approach (e.g. Luedecke et al., 1989);

- A combined chemical equilibrium-kinetic model approach (e.g. Briggs, 1996);

- A kinetic model approach (e.g. Henze et al., 1995).

The aim of this paper is to review these three approaches in detail in order to compare their relative merits and hence, to select one as a means of modelling the data gathered during the experimental investigation on simultaneous chemical-biological Premoval carried out during this study (Parts 3, $4 \& 5$ of this series of papers - De Haas et al. 2000a, b; 2001).

\section{The chemical model of Luedecke et al. (1989)}

Luedecke et al. (1989) developed a chemical model for phosphate precipitation with ferric (iron III) salts in aqueous systems and applied it to a conventional activated sludge system. Their model represents an important contribution towards developing a combined chemical-biological model for Premoval in activated sludge systems and is worthy of detailed examination. 


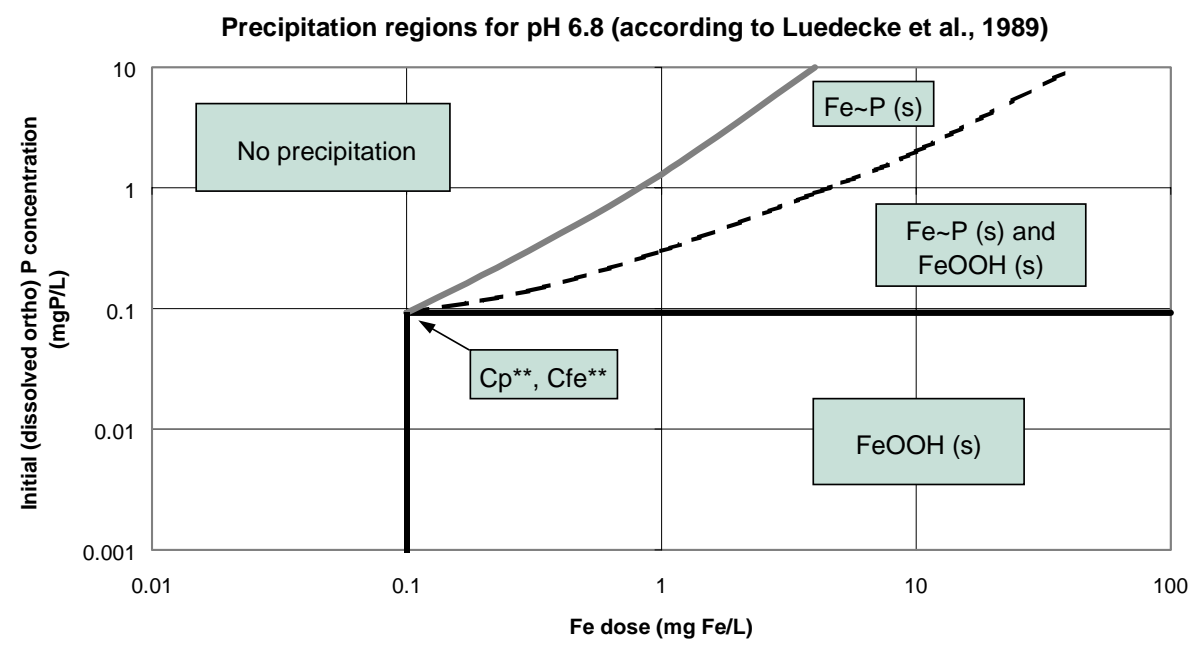

Figure 1

Precipitation regions at $\mathrm{pH} 6.8$ for iron (III) and phosphate according to Luedecke et al. (1989). Refer to text for definition of $C_{p}{ }^{* *}$ and $C_{f e}{ }^{* *}$.

$\mathrm{Fe}_{\mathrm{r}} \mathrm{PO}_{4}(\mathrm{OH})_{3 r-3}$ is abbreviated as $\mathrm{Fe} \sim \mathrm{P}$.

Luedecke et al. (1989) pointed out that the chemistry of phosphate in aqueous solutions is not fully understood even though there have been a number of studies on this subject. Since inorganic phosphates are known to combine with a number of metal ions to form chelates, complexes or insoluble salts, determination of the composition of precipitates becomes problematic. A general formula for ferric hydroxy-orthophosphate, namely $\mathrm{Fe}_{\mathrm{r}} \mathrm{PO}_{4}(\mathrm{OH})_{3 \mathrm{r}-3}$, was reported by Stumm and Morgan (1970) (cited by Luedecke et al., 1989) as one of the solid phases that may occur in natural aqueous environments. Luedecke et al. (1989) accepted this formula and that for amorphous ferric hydroxide $(\mathrm{FeOOH})$ as the two principal forms of iron precipitate that could exist in activated sludge. Since their model involved two precipitates, they postulated that four possible precipitation "regions" could exist, namely (Fig. 1):

- $\mathrm{Fe}_{\mathrm{r}} \mathrm{PO}_{4}(\mathrm{OH})_{3 \mathrm{r}-3}$ (s) precipitation;

- $\mathrm{FeOOH}(\mathrm{s})$ precipitation;

- Co-precipitation of $\mathrm{Fe}_{\mathrm{r}} \mathrm{PO}_{4}(\mathrm{OH})_{3 \mathrm{r}-3}$ (s) and $\mathrm{FeOOH}(\mathrm{s})$;

- No precipitation

The conditions applying to each of these four regions may be summarised as follows (Luedecke et al., 1989):

\section{Co-precipitation of $\mathrm{Fe}_{\mathrm{r}} \mathrm{PO}_{4}(\mathrm{OH})_{3 \mathrm{r}-3}(\mathrm{~s})$ and FeOOH (s)}

If the dose of $\mathrm{Fe}$ is sufficiently high and the initial orthoP concentration is not limiting, both ferric hydroxy-phosphate and ferric hydroxide will precipitate:

$$
\begin{aligned}
& \mathrm{r} \mathrm{Fe}^{3+}+\mathrm{PO}_{4}^{3-}+(3 \mathrm{r}-3) \mathrm{OH}^{-} \circledast \mathrm{Fe}_{\mathrm{r}} \mathrm{PO}_{4}(\mathrm{OH})_{3 \mathrm{r}-3}(\mathrm{~s}) \quad \mathrm{pK}_{\mathrm{s}}=? ? \\
& \mathrm{Fe}^{3+}+2 \mathrm{H}_{2} \mathrm{O} \otimes \mathrm{FeOOH}(\mathrm{s}) \text { (amorphous) }+3 \mathrm{H}^{+} \quad \mathrm{pK}=-0.5
\end{aligned}
$$

Based on Eq. 1 and 2, expressions were developed from equilibrium chemistry for the maximum concentrations of dissolved orthophosphate $\left(\mathrm{c}_{\mathrm{p}}^{* *}\right)$ and dissolved iron $\left(\mathrm{c}_{\mathrm{Fe}}{ }^{* *}\right)$ which can co-exist in equilibrium with $\mathrm{Fe}_{\mathrm{r}} \mathrm{PO}_{4}(\mathrm{OH})_{3 \mathrm{r}-3}$ and $\mathrm{FeOOH}$ at a particular $\mathrm{pH}$ under conditions of co-precipitation. [The double asterisk is used to indicate equilibrium concentrations of $P\left(c_{p}^{* *}\right)$ or $\mathrm{Fe}\left(c_{F e}{ }^{* *}\right)$ under conditions of co-precipitation]. In these expressions ionpairing effects were taken into account: dissolved orthophosphate species included iron complexes (viz. $\mathrm{FeH}_{2} \mathrm{PO}_{4}{ }^{2+}$ and $\mathrm{FeHPO}_{4}^{+}$) and dissolved iron species included complexes with phosphate or hydroxide (viz. $\mathrm{FeOH}^{2+} ; \mathrm{Fe}(\mathrm{OH})_{2}^{+}$; $\mathrm{Fe}(\mathrm{OH})_{3}{ }^{0} ; \mathrm{Fe}(\mathrm{OH})_{4} ; \mathrm{FeH}_{2} \mathrm{PO}_{4}{ }^{2+}$ and $\mathrm{FeHPO}_{4}^{+}$).

Ferric phosphate $\left(\mathrm{FePO}_{4}\right)$ and ferric hydroxy-phosphate $\left(\mathrm{Fe}_{\mathrm{r}} \mathrm{PO}_{4}(\mathrm{OH})_{3 \mathrm{r}-3}\right)$ have low solubility products: $\mathrm{pK}_{\mathrm{s}}=23$ for amorphous $\mathrm{FePO}_{4} ; \mathrm{pK}_{\mathrm{s}}=28.7$ for $\mathrm{FePO}_{4}$ as strengite; and Luedecke et al. (1989) estimated $\mathrm{pK}_{\mathrm{s}}=96.7$ for $\mathrm{Fe}_{\mathrm{r}} \mathrm{PO}_{4}(\mathrm{OH})_{3 \mathrm{r}-3}$ ) from calibration of their model to experimental data (see below). The large $\mathrm{pK}_{\mathrm{s}}$ value for $\left.\mathrm{Fe}_{\mathrm{r}} \mathrm{PO}_{4}(\mathrm{OH})_{3 \mathrm{r}-3}\right)$ implies that ferric hydroxy-phosphate precipitation essentially will be complete. This could be conceptualised as ferric hydroxyphosphate forming in preference to ferric hydroxide (i.e. being thermodynamically more stable), although this should not be interpreted in kinetic terms here. Hence, for co-precipitation the concentration of ferric hydroxy-phosphate precipitate formed $\left(c_{p, p r e}\right)$ could be determined by the difference between the initial (or "influent") dissolved orthophosphate concentration $\left(\mathrm{c}_{\mathrm{p}, \mathrm{in}}\right)$ and $\mathrm{c}_{\mathrm{p}} * *$ :

$$
\mathrm{c}_{\mathrm{p}, \text { prec }}=\mathrm{c}_{\mathrm{p}, \mathrm{in}}-\mathrm{c}_{\mathrm{p}} * *
$$

Similarly, the amount of ferric hydroxide precipitate formed was found from the $\mathrm{Fe}(\mathrm{III})$ mass balance (i.e. $\mathrm{Fe}(\mathrm{III})$ dose $-\mathrm{c}_{\mathrm{Fe}} * *$ $\mathrm{Fe}(\mathrm{III})$ removed stoichiometrically as $\left.\mathrm{Fe}_{\mathrm{r}} \mathrm{PO}_{4}(\mathrm{OH})_{3 \mathrm{r}-3}\right)$ :

$$
\mathrm{c}_{\mathrm{Fe}, \text { prec }}=\mathrm{c}_{\mathrm{Fe}, \text { dose }}-\mathrm{c}_{\mathrm{Fe}} * *-\mathrm{r}\left(\mathrm{c}_{\mathrm{p}, \text { in }}-\mathrm{c}_{\mathrm{p}} * *\right)
$$

Since co-precipitation ceases when no ferric hydroxide precipitate forms, the boundary between the co-precipitation region and the ferric hydroxy-phosphate region was defined by the condition:

$$
\mathrm{c}_{\mathrm{Fe}, \text { dose }}-\mathrm{c}_{\mathrm{Fe}} * *=\mathrm{r}\left(\mathrm{c}_{\mathrm{p}, \text { in }}-\mathrm{c}_{\mathrm{p}} * *\right)
$$

Typically at near-neutral $\mathrm{pH}$, co-precipitation was expected in the region of low initial dissolved orthoP concentrations (e.g. $c_{p, i n} \sim 0.3$ to $2 \mathrm{mgP} / \mathrm{l}$ ) for an iron dose of $\sim 1$ to $10 \mathrm{mg} / \mathrm{l}$ as $\mathrm{Fe}$ - refer to dashed line in Fig. 1).

\section{Precipitation of $\mathrm{FeOOH}(\mathrm{s})$ only}

If the initial orthophosphate concentration $\left(\mathrm{c}_{\mathrm{p}, \mathrm{in}}\right)$ is less than $\mathrm{c}_{\mathrm{p}}{ }^{* *}$, then ferric hydroxy-phosphate precipitate will not form; only ferric hydroxide will form, provided the $\mathrm{Fe}(\mathrm{III})$ dose exceeds $\mathrm{c}_{\mathrm{Fe}} * *$. Hence, a boundary between co-precipitation and ferric hydroxide precipitation could be defined as $c_{p, i n}=c_{p}^{* *}$. Similarly, a boundary between ferric hydroxide precipitation and no precipitation could be defined as $\mathrm{c}_{\mathrm{Fe} \text {, dose }}=\mathrm{c}_{\mathrm{Fe}} * *$.

At near-neutral $\mathrm{pH}$, using the solubility product and dissociation constant values assumed by Luedecke et al. (1989), ferric hydroxide precipitation only may be expected in the region of low initial dissolved orthoP concentrations $(<0.1 \mathrm{mgP} / \ell)$ and iron doses of $>0.1 \mathrm{mg} \mathrm{Fe} / \ell$ (Fig. 1).

\section{Precipitation of FerPO4(OH)3r-3 (s) only}

Since ferric hydroxy-phosphate is very insoluble and is considered to form "preferentially" to ferric hydroxide, a boundary could be 
defined between the condition of no precipitation (i.e. neither precipitate with only soluble iron-phosphate and iron-hydroxide ion pairs/complexes present) and the onset of ferric hydroxyphosphate precipitation. Since the equation describing this boundary could not be expressed explicitly, an implicit form had to be derived by tedious algebraic manipulations based on assumed solubility and dissociation constant values and the equilibrium equations for the respective species over a range of the two variables, iron dose $\left(\mathrm{c}_{\mathrm{Fe}, \text { dose }}\right)$ and initial (or influent) dissolved orthoP concentration $\left(\mathrm{c}_{\mathrm{p}, \mathrm{in}}\right)$.

\section{Adsorption}

Using the precipitation model described above, Luedecke et al. (1989) calculated equilibrium (residual) orthoP concentrations ( $\mathrm{c}_{\mathrm{P}, \mathrm{res}}$, including ion pairs) for a range of $\mathrm{Fe}$ (III) doses likely to be encountered in activated sludge systems. Batch tests were carried out with activated sludge samples dosed with orthoP and ferric (iron III) chloride in the same range. Comparing calculated and experimentally observed data, they found that the observed $\mathrm{Fe}_{\text {dose }} /$ $\mathrm{P}_{\text {removed }}(\mathrm{Fe} / \mathrm{P})$ ratios were consistently lower than the calculated ratios in the range where $c_{\mathrm{P}_{\text {res }}}$ was low (ca. $<0.5 \mathrm{mgP} / \ell$ ). This discrepancy was postulated to be due to adsorption of phosphate onto the formed precipitate. Luedecke et al. (1989) further proposed that adsorption of phosphate ions occurs onto both ferric hydroxyphosphate and ferric hydroxide (if present in the system). The concentration of adsorbed phosphate was considered to be proportional to the amount of adsorbing precipitate and remaining in equilibrium with the residual phosphate and hydroxide concentrations. By lumping the two types of precipitate, Luedecke et al. (1989) proposed a simple mass transfer model to describe the adsorption reaction, in which the key unknown is the adsorption coefficient $\left(\mathrm{K}_{\mathrm{a}}\right)$ :

$$
\mathrm{c}_{\mathrm{P}, \mathrm{ads}}=\mathrm{K}_{\mathrm{a}} \cdot \mathrm{X}_{\mathrm{a}} \cdot\left[\mathrm{PO}_{4}{ }^{3-}\right]_{\mathrm{res}} /\left[\mathrm{OH}^{-}\right]
$$

where:

$\mathrm{c}_{\mathrm{P}, \text { ads }}$ is the concentration of orthoP adsorbed on the precipitate $\mathrm{K}$, is the adsorption coefficient

$\mathrm{X}_{\mathrm{a}}$ is the concentration of precipitate in the system, calculated from the sum of the concentration of iron precipitated (in the case of ferric hydroxide) and $P$ precipitated (in the case of ferric hydroxy-phosphate), adjusted for the number of hydroxyl groups available (i.e. 1 per $\mathrm{Fe}$ for ferric hydroxide; (3r-3) per Fe for ferric hydroxy phosphate); and $\mathrm{PO}_{4 \text { res }}^{3-}\left(\right.$ or $\left.\mathrm{C}_{\mathrm{P}, \mathrm{res}}\right)$ is the residual orthoP concentration considered to be "dissolved", taking into account phosphate weak acid/ base speciation and ion pair formation. [Luedecke et al. (1989) appear to have used the terms $\mathrm{PO}_{4}^{3-}$ res and $\mathrm{c}_{\mathrm{p}, \mathrm{res}}$ interchangeably; i.e. that the $\mathrm{PO}_{4}^{3-}$ term in Eq. 6 includes all the soluble ion pair complexes for P. Since the rate constant in Eq. 6 would need to be determined from analytical measurements of dissolved orthoP, including ion pairs and weak acid/base species other than $\mathrm{PO}_{4}^{3-}$, we assume this to be correct].

\section{Summary of Luedecke et al. (1989) model}

In summary, the complete model of Luedecke et al. (1989) consists of equilibrium equations describing the reactions of orthophosphate species dissociation and iron ion pair complexation with phosphate or hydroxide, mass balance equations for phosphate and iron, equations defining the split between the type of precipitate formed at a given $\mathrm{pH}$ and an associated adsorption equilibrium. After solving these equations, it is possible to obtain the value of dissolved orthophosphate $\left(\mathrm{c}_{\mathrm{P}, \mathrm{eq}}\right)$ in equilibrium with the precipitate(s) for a given $\mathrm{pH}$, initial phosphate concentration and $\mathrm{Fe}$ (III) dose. $\mathrm{c}_{\mathrm{P}, \mathrm{eq}}$ is further partitioned between an adsorbed fraction $\left(\mathrm{c}_{\mathrm{P}, \mathrm{ads}}\right)$ and a residual fraction $\left(\mathrm{c}_{\mathrm{p} \text { res }}\right)$, which is that measured analytically in the dissolved phase:

$$
\mathrm{c}_{\mathrm{P}, \mathrm{eq}}=\mathrm{c}_{\mathrm{P}, \mathrm{ads}}+\mathrm{c}_{\mathrm{P}, \mathrm{res}}
$$

\section{Experimental vs. model results of Luedecke et al. (1989) and estimation of unknowns}

The model of Luedecke et al. (1989) contains four parameters with unknown values:

- the stoichiometric coefficient, $r$, in $\mathrm{Fe}_{\mathrm{r}} \mathrm{PO}_{4}(\mathrm{OH})_{3 \mathrm{r}-3}$

- the solubility product, $\mathrm{K}_{\mathrm{sp}}$, for $\mathrm{Fe}_{\mathrm{r}} \mathrm{PO}_{4}(\mathrm{OH})_{3 \mathrm{r}-3}$

- the equilibrium (stability) constant $\left(\mathrm{K}_{\mathrm{fp}}\right)$ for the iron-phosphate ion pair complex $\mathrm{FeH}_{2} \mathrm{PO}_{4}^{2+}$

- the adsorption coefficient $\left(\mathrm{K}_{\mathrm{a}}\right)$.

Luedecke et al.(1989) evaluated these unknowns from experimental results of batch and continuous tests for simultaneous dosing of ferric chloride to activated sludge under aerobic conditions with strict $\mathrm{pH}$ control ( $\mathrm{pH} 7.2$ for continuous tests and either $\mathrm{pH}$ 6.8, 7.2 or 8.0 for batch tests). The experiments took into account the observation that during the first hour of aeration, hydrolysis of complex forms of phosphate (mainly of particulate origin) to dissolved orthophosphate occurred.

Luedecke et al. (1989) found good agreement between the observed and calculated (model) results. Their model results are shown in Fig. 2. All the observed $\mathrm{Fe}_{\text {dosed }} / \mathrm{P}_{\text {removed }}$ curves (Fig. 2) exhibited the following common features:

- Moving from high (ca. $6 \mathrm{mgP} / \ell$ ) to lower (ca. 0.5 to $2 \mathrm{mgP} / \ell$ ) residual orthoP concentrations, there was a slow increase in the $\mathrm{Fe} / \mathrm{P}$ ratio during the period when only ferric hydroxy-phosphate precipitation was predicted. The fact that the $\mathrm{Fe} / \mathrm{P}$ ratio was not constant in this region prior to ferric hydroxide formation implied that the composition of the precipitate was not constant under these conditions. Luedecke et al. (1989) accommodated this change by means of the adsorption process in their model. However, they did note that $\mathrm{P}$ adsorption onto the biological mixed liquor suspended solids could not be ruled out.

- A sharp increase in the $\mathrm{Fe} / \mathrm{P}$ ratio occurred at low $\mathrm{P}$ concentrations when ferric hydroxide precipitation commenced.

By means of fitting calculated (model) data (Fig. 2) to the observed values, Luedecke et al. (1989) concluded that the composition of ferric hydroxy-phosphate formed in their experimental systems was essentially the same for all $\mathrm{pH}$ values. All estimates were distributed around a mean value of $\mathrm{r}=2.5 \mathrm{~mol} \mathrm{Fe} / \mathrm{mol} \mathrm{P}$, which gives the empirical formula of $\mathrm{Fe}_{2.5} \mathrm{PO}_{4}(\mathrm{OH})_{4.5}$. The estimated $\mathrm{pK}$ value for this precipitate was 96.7. This value is much lower than the literature value for $\mathrm{FePO}_{4}$ as strengite $\left(\mathrm{pK}_{\mathrm{s}}=28.7\right)$ or amorphous $\mathrm{FePO}_{4}\left(\mathrm{pK}_{\mathrm{s}}=23\right)$. From their results, supported by similar data from an independent source, Luedecke et al. (1989) concluded that the solubility of ferric (hydroxy) phosphate precipitating in activated systems is much lower than in pure chemical systems.

The value of the equilibrium constant $\left(\mathrm{K}_{\mathrm{fp}}\right)$ for the reaction $\mathrm{Fe}^{3+}+\mathrm{H}_{2} \mathrm{PO}_{4}{ }^{-} \hat{\mathrm{U}} \quad \mathrm{FeH}_{2} \mathrm{PO}_{4}{ }^{2+}$ was reported to vary over a wide range in the literature. Since the formation of this complex significantly influences residual orthoP solubility at low $\mathrm{pH}$, Luedecke et al. (1989) estimated the value of this equilibrium constant from experimental results. The mean estimated value for $\mathrm{pK}_{\mathrm{fp}}$ was -21.5 , 
Simultaneous precipitation using ferric chloride Model of Luedecke et al. (1989)

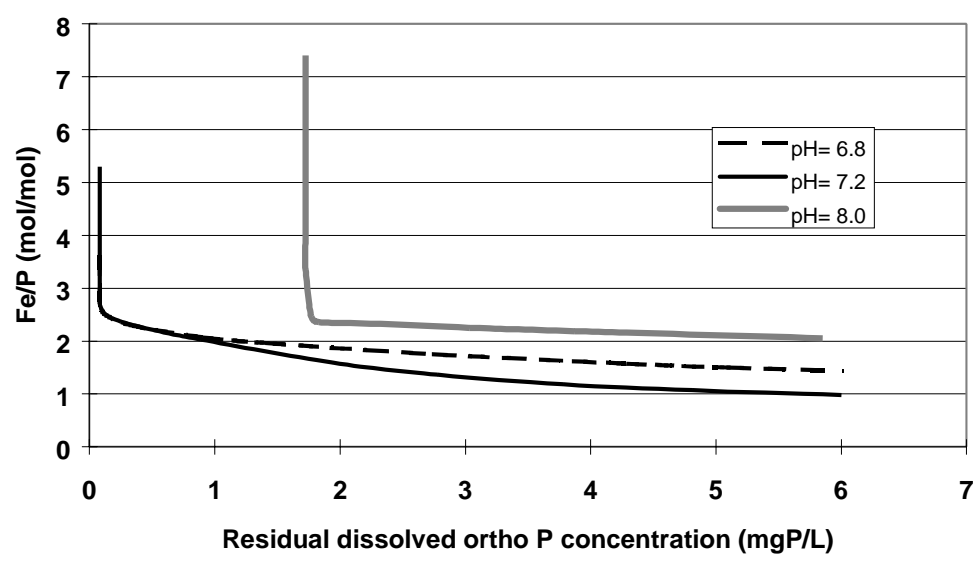

Figure 2

Theoretical $\mathrm{Fe}$ (dosed)/ $P$ (removed) molar ratio as a function of residual ortho $P$ concentrations $\left(c_{P, \text { res }}\right)$, according to the model of Luedecke et al. (1989).

Refer to Luedecke et al., 1989, for full data sets (observed and theoretical). metal ions surplus to the precipitation of metal hydroxy-phosphate will precipitate as metal hydroxide. This has the apparent effect of significantly increasing the ratio of metal (dosed): $\mathrm{P}$ (removed);

- The degree of phosphorus removal is dependent on two main factors: the metal:P ratio at the point of addition and the final $\mathrm{pH}$ after metal salt addition;

- At high metal salt doses, both hydroxy-phosphate and hydroxide precipitates may be expected to be present, with the (low) residual phosphate concentration being strongly influenced by $\mathrm{pH}$; and

- Adsorption of phosphate onto metal hydroxide (or metal hydroxy-phosphate) precipitate can be used to "make up the difference" between precipitation predictions and experimental results. although some uncertainty in the range -20.7 to -22.7 was noted for the $\mathrm{pH}$ range 6.8 to 8.0 (Luedecke et al., 1989).

Considerable uncertainty arose in estimating the value of the adsorption coefficient $\left(\mathrm{K}_{\mathrm{a}}\right)$ at low (6.5) or high (8.0) $\mathrm{pH}$. Less uncertainty in the data was evident in the $\mathrm{pH}$ range 6.8 to 7.2 , and $\mathrm{K}_{\mathrm{a}}$ appeared to be at a minimum at $\mathrm{pH}$ ca. 7.0. The combined data gave a mean $\mathrm{K}_{\mathrm{a}}=1.68 \times 10^{-12} \mathrm{~mol}^{2} / \ell^{2}$; in the $\mathrm{pH}$ range 6.8 to 7.2 , the mean $\mathrm{K}_{\mathrm{a}}$ was 0.99 to $1.90 \times 10^{-12} \mathrm{~mol}^{2} / \ell^{2}$; and at $\mathrm{pH} 8.0$, the mean $\mathrm{K}$ was $4.1 \times 10^{-12} \mathrm{~mol}^{2} / \ell^{2}$. Luedecke et al. (1989) noted that the variation in the value of $\mathrm{K}_{\mathrm{a}}$ is probably an indication that their hypothetical adsorption mechanism is over-simplistic and does not fully describe the actual phenomenon.

\section{The chemical model of Briggs (1996)}

Using the steady-state model of Luedecke et al. (1989) as a starting point, Briggs (1996) developed a model describing simultaneous chemical P removal in activated sludge systems. Following its development, Briggs (1996) incorporated this precipitation model into a dynamic activated sludge simulation program and tested its effectiveness. The model proposed by Briggs (1996) combines equilibrium chemistry and kinetic approaches for the chemical $\mathrm{P}$ removal processes. It is more fundamental than models that follow the kinetic approach alone, such as IAWQ ASM Model No. 2 (Henze et al., 1995). The model of Briggs (1996) warrants detailed examination in order to draw comparisons later with the IAWQ model. A summary of the Briggs model is also given by Dold and Briggs (1995).

\section{Basis of the Briggs chemical model}

Certain fundamental assumptions in the Briggs (1996) model for chemical P removal were based on the work of Luedecke et al. (1989), namely:

- Chemical reactions at the point of metal salt addition are assumed to be instantaneous;

- Phosphate is removed through the ("preferential") formation of metal hydroxy-phosphate precipitate;

- Once a critical (low) residual phosphate concentration is reached,
As further evidence that adsorption is an important chemical P removal mechanism, Briggs (1996) cited the work of Rabinowitz and Marais (1980) and Siebritz et al. (1983) which demonstrated that simultaneously dosed activated sludge systems showed a "persistence effect" in that low effluent $\mathrm{P}$ concentrations could be maintained for a number of days after metal salt addition was discontinued. However, Briggs (1996) also pointed out that no studies appear to have isolated and reviewed adsorption as a chemical removal mechanism per se in activated sludge systems. On the other hand, many studies have been reported on phosphate removal in soil, including adsorption to ferric hydroxide (or goethite, $\mathrm{FeOOH}$ ) and aluminium hydroxide (gibbsite, $\mathrm{AlOH}_{3}$ ). From a review of the soil science literature, Briggs (1996) drew the following conclusions:

- Phosphorus adsorption involves replacement of hydroxyl groups with orthophosphate ions, and phosphate groups tend to form bonds which bridge between two adjacent metal hydroxide molecules. The general mechanism can be represented as:

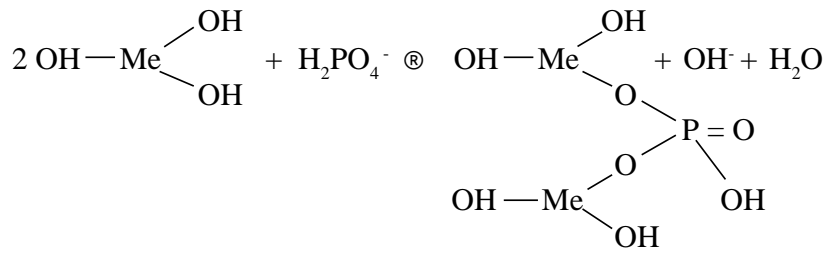

- Adsorption capacity for phosphate on metal hydroxide appears to reduce with time. For example, for ferric hydroxide, one study showed a reduction from $1.5 \mathrm{~mol} \mathrm{P}_{\text {adsorbed }} / \mathrm{mol} \mathrm{Fe}$ to 0.2 mol $\mathrm{P}_{\text {adsorbed }} / \mathrm{mol} \mathrm{Fe}$ after ageing the precipitate for one day.

- There is evidence that the kinetics of adsorption on metal hydroxides shows an initial rapid adsorption (e.g. over the first day), followed by a slower adsorption period. Some studies have attempted to describe the kinetics as two first order reactions. Others have recommended the use of an Elovichtype equation for this purpose. According to Briggs (1996), the general form of the Elovich equation is:

$$
\underline{d q}=\mathrm{a} \exp (-\mathrm{bq})
$$

$$
d \mathrm{t}
$$

where:

$$
\begin{aligned}
\mathrm{q}= & \text { mass of adsorbate (i.e. } \mathrm{P} \text { ) taken up per unit solid } \\
& \text { mass (i.e. metal hydroxide) }
\end{aligned}
$$


tion reaction

$\mathrm{b}=\mathrm{a}$ constant relating to the activation energy for adsorption

The Elovich-type equation in this context assumes that the activation energy increases linearly as a function of q (i.e. giving a relatively high rate of adsorption when $q$ is small, but tapering off as q increases).

\section{Influent phosphorus fractions}

In order to integrate the chemical precipitation model into the biological model, Briggs (1996) proposed fractions for the influent phosphorus along similar lines to that for nitrogen in the IAWQ (IAWPRC) ASM Model No. 1. Five influent phosphorus fractions were proposed, collectively comprising the influent total $\mathrm{P}$, namely: soluble orthoP $\left(\mathrm{P}_{\mathrm{pi}}\right)$; soluble unbiodegradable organic $\mathrm{P}\left(\mathrm{P}_{\mathrm{ui}}\right)$, particulate unbiodegradable organic $\mathrm{P}\left(\mathrm{P}_{\mathrm{xi}}\right)$; particulate biodegradable organic $\mathrm{P}\left(\mathrm{P}_{\mathrm{ei}}\right)$; and soluble biodegradable organic $\mathrm{P}\left(\mathrm{P}_{\mathrm{oi}}\right)$. OrthoP $\left(\mathrm{P}_{\mathrm{p}}\right)$ is readily determined colorimetrically after filtration (e.g. Standard Methods, 1985). Phosphorus other than orthoP is considered to be organic $\mathrm{P}$, in four sub-fractions $\left(\mathrm{P}_{\mathrm{ui}}, \mathrm{P}_{\mathrm{xi}}, \mathrm{P}_{\mathrm{ei}}, \mathrm{P}_{\mathrm{oi}}\right) . \mathrm{P}_{\mathrm{ui}}$ is considered to be negligible (Briggs, 1996). $\mathrm{P}_{\mathrm{xi}}$ is modelled as a fraction of the inert particulate influent COD $\left(\mathrm{X}_{\mathrm{ii}}\right)$, based on the total P/VSS ratio (converted to total P/COD) for biomass not exhibiting excess biological $\mathrm{P}$ removal capacity (e.g. 0.025 $\mathrm{mgP} / \mathrm{mg} \mathrm{VSS}$ ). $\mathrm{P}_{\mathrm{ei}}$ is modelled as a fraction of the slowly biodegradable (particulate) COD fraction. $\mathrm{P}_{\mathrm{oi}}$ is found from the difference:

$$
\mathrm{P}_{\mathrm{oi}}=\mathrm{P}_{\mathrm{ti}}-\mathrm{P}_{\mathrm{pi}}-\mathrm{P}_{\mathrm{ei}}-\mathrm{P}_{\mathrm{ui}}-\mathrm{P}_{\mathrm{xi}}
$$

\section{Point of addition of metal salt}

For the sake of simplicity, the precipitation model of Briggs (1996) was only developed for a metal salt addition point immediately following the aeration basin. This should be analogous to addition to the aeration tank itself under completely mixed conditions. The most common dosing points are the aeration basin or the line leading from the aeration basin to the secondary clarifiers. For modelling purposes, these points also have the advantage that the concentration of complexing soluble organics is low and most of the soluble phosphorus is in the orthoP form (i.e. biological hydrolysis of organic $\mathrm{P}$ and biological $\mathrm{P}$ uptake are essentially complete).

\section{Precipitation processes}

In view of the lack of consensus on the types of precipitate formed during phosphorus precipitation using metal salts in wastewater treatment systems, Briggs (1996) followed the approach of Luedecke et al. (1989) and adopted the general formula for a fictitious precipitate as the basis for an equilibrium model. The equilibrium expression for the fictitious precipitate may be written as (c.f. Eq. 1):

$$
\mathrm{rMe}^{3+}+\mathrm{PO}_{4}^{3-}+(3 \mathrm{r}-3) \mathrm{H}_{2} \mathrm{O} \ll \mathrm{Me}_{\mathrm{r}} \mathrm{PO}_{4}(\mathrm{OH})_{3 \mathrm{r}-3}+(3 \mathrm{r}-3) \mathrm{H}^{+}
$$

In Eq. 9, $\mathrm{Me}^{3+}$ is the trivalent metal ion. The value of $\mathrm{r}$ can be adjusted to represent the stoichiometry of precipitation, typically determined at high initial P: low metal dose ratios (e.g. in jar tests). In the model application, Briggs (1996) opted to use $r=1$ for both alum and ferric salt addition (i.e. $\mathrm{MePO}_{4}$ precipitate) because this simple precipitate gave reasonable results (see later).

At high metal dose: $\mathrm{P}$ ratios, metal hydroxide co-precipitation is expected, thereby reducing the overall stoichiometry of Premoval:

$$
\mathrm{Me}^{3+}+\mathrm{H}_{2} \mathrm{O} \ll \mathrm{Me}(\mathrm{OH})_{3}+\mathrm{H}^{+}
$$

\section{Precipitation processes and equilibrium considerations}

Briggs (1996) applied a first order expression that relates Premoval through precipitation to the initial metal: $\mathrm{P}$ ratio. This expression was used by Narasiah et al. (1991) to model simultaneous precipitation with ferric chloride or alum as an empirical exponential decline expression. It relates the residual phosphorus concentration after precipitation to the initial metal:P ratio at the point of chemical dosing:

$$
\frac{\mathrm{P}_{\mathrm{r}}}{\mathrm{P}_{\mathrm{P} 0}}=\mathrm{e}^{-\mathrm{a}\left(\mathrm{Me}_{0}: \mathrm{P}_{\mathrm{P} 0}\right)}
$$

where:

$$
\begin{aligned}
\mathrm{P}_{\mathrm{r}}= & \text { residual } \mathrm{P} \text { concentration after precipitation }(\mathrm{mgP} / \ell) ; \\
\mathrm{P}_{\mathrm{P} 0}= & \text { initial } \mathrm{P} \text { concentration (before precipitation) } \\
& (\mathrm{mgP} / \ell) ; \\
\mathrm{Me}_{0}: \mathrm{P}_{\mathrm{P} 0}= & \text { ratio of metal (dosed) to initial (orthoP) concentra- } \\
& \text { tion }(\mathrm{mgMe} / \mathrm{mgP}) ; \\
\mathrm{a} \quad & \text { constant relating to stoichiometry of removal } \\
& (\mathrm{mg} \mathrm{P} / \mathrm{mg} \mathrm{Me}) .
\end{aligned}
$$

In Eq. 11, the residual $\mathrm{P}\left(\mathrm{P}_{\mathrm{r}}\right)$ and initial $\mathrm{P}\left(\mathrm{P}_{\mathrm{p0}}\right)$ concentrations include all phosphate weak/base species (i.e. $\mathrm{PO}_{4}{ }^{3-}+\mathrm{HPO}_{4}{ }^{2-}+$ $\mathrm{H}_{2} \mathrm{PO}_{4}^{-}+\mathrm{H}_{3} \mathrm{PO}_{4}$ ) and any ion pair complexes with these species.

Equation 11 was re-written in linear form and a second constant introduced:

$$
\ln \left(\mathrm{P}_{\mathrm{r}} / \mathrm{P}_{\mathrm{P} 0}\right)=\ln \mathrm{a}_{1}-\mathrm{a}_{2} \cdot\left(\mathrm{Me}_{0}: \mathrm{P}_{\mathrm{P} 0}\right)
$$

where $\mathrm{a}$ in Eq. 11 becomes $\mathrm{a}_{2}$, and $\mathrm{a}_{1}(\mathrm{mgP} / \mathrm{mgP})$ relates to the minimum metal dose required to initiate precipitation. At low metal salt dose, where $\mathrm{a}_{2}\left(\mathrm{Me}_{0}: \mathrm{P}_{\mathrm{P} 0}\right)<\ln \mathrm{a}_{1}$, Eq. 12 will predict $\mathrm{P}_{\mathrm{r}}>\mathrm{P}_{\mathrm{P} 0}$ (impossible), implying that no $\mathrm{P}$ is precipitated. The value of $\mathrm{a}_{1}$ is expected to vary, depending on wastewater characteristics and point of metal dosing. Numerous authors indicate that increased metal dosages are required to initiate precipitation in preprecipitation systems. In such applications, the value of $a_{1}$ is expected to be greater than unity. However, for simultaneous (or post) precipitation applications, where the concentration of metalcomplexing organics in the soluble phase is expected to be negligible, Briggs (1996) assumed the value of $a_{1}$ to be unity.

Equation 12 can be written in exponential form to give:

$$
\mathrm{P}_{\mathrm{r}}=\mathrm{a}_{1} \mathrm{P}_{\mathrm{P} 0} \mathrm{e}^{-\mathrm{a}\left(\mathrm{Me}_{0}: \mathrm{P}_{\mathrm{P} O}\right)}
$$

In Eqs. 12 and 13 above, for a given initial $\mathrm{P}$ concentration $\left(\mathrm{P}_{\mathrm{P} 0}\right)$, the residual $\mathrm{P}$ concentration $\left(\mathrm{P}_{\mathrm{r}}\right)$ is controlled by the amount of metal dosed $\left(\mathrm{Me}_{0}\right)$. However, under certain conditions (typically at high dose ratios of metal: $\mathrm{P}$ and/or low $\mathrm{pH}$ ), the residual $\mathrm{P}$ concentration may be controlled by equilibrium (i.e. solubility of the precipitate becomes significant). Under these conditions it is necessary to replace the residual $\mathrm{P}$ concentration $\left(\mathrm{P}_{\mathrm{r}}\right)$ in Eq. 13 with the equilibrium residual predicted from the solubility products.

The minimum ( $\mathrm{pH}$ dependent) residual orthoP $\left(\mathrm{PO}_{4}^{3-}\right)$ and free metal concentrations derived from the solubility products of the precipitates were calculated by Briggs (1996) as follows:

$$
\begin{aligned}
\mathrm{K}_{\mathrm{MeP}} & =\left[\mathrm{Me}^{3+}\right]^{\mathrm{r}}\left[\mathrm{PO}_{4}^{3-}\right]\left[\mathrm{OH}^{-}\right]^{3 \mathrm{r}-3} \\
\mathrm{~K}_{\mathrm{MeH}} & =\left[\mathrm{Me}^{3+}\right]\left[\mathrm{OH}^{-}\right]
\end{aligned}
$$


Substituting and rearranging:

$$
\begin{aligned}
& {\left[\mathrm{Me}^{3+}\right]=\mathrm{K}_{\mathrm{MeH}} /\left[\mathrm{OH}^{-}\right]^{3}} \\
& {\left[\mathrm{PO}_{4}{ }^{3-}\right]=\mathrm{K}_{\mathrm{MeP}} /\left(\mathrm{K}_{\mathrm{MeH}}\right)^{\mathrm{r}} \cdot\left[\mathrm{OH}^{-}\right]^{3}}
\end{aligned}
$$

From Eqs. 14 and 15 above, for a given $\mathrm{pH}$ (ie. $\left[\mathrm{OH}^{-}\right]$), free metal and orthoP (i.e. $\left[\mathrm{PO}_{4}^{3-}\right]$ ) concentrations can be derived. These concentrations need to be corrected to take account of ion pair complexes and phosphate weak acid/base species other than $\mathrm{PO}_{4}^{3-}$. To do this, Briggs (1996) derived the following equations:

$$
\begin{aligned}
\mathrm{P}_{\mathrm{P} \text { res }}= & 1000 \mathrm{AM}_{\mathrm{p}}\left[\mathrm{PO}_{4}{ }^{3-}\right]\left\{1+\left[\mathrm{H}^{+}\right] / \mathrm{k}_{\mathrm{p}, 3}\right. \\
& +\left[\mathrm{H}^{+}\right]^{2} /\left(\mathrm{k}_{\mathrm{p}, 2} \mathrm{k}_{\mathrm{p}, 3}\right)\left(1+\mathrm{k}_{\mathrm{MHP}}\left[\mathrm{Me}^{3+}\right]\right) \\
& \left.+\left[\mathrm{H}^{+}\right]^{3} /\left(\mathrm{k}_{\mathrm{p}, 1} \mathrm{k}_{\mathrm{p}, 2} \mathrm{k}_{\mathrm{p}, 3}\right)\right\}
\end{aligned}
$$

$\mathrm{Me}_{\mathrm{T}}=1000 \mathrm{AM}_{\mathrm{Me}}\left[\mathrm{Me}^{3+}\right]\left\{1+\mathrm{k}_{\mathrm{Me}, 1} /\left[\mathrm{H}^{+}\right]\right.$

$+\mathrm{k}_{\mathrm{Me}, 2} /\left[\mathrm{H}^{+}\right]^{2}+\mathrm{k}_{\mathrm{Me}, 3} /\left[\mathrm{H}^{+}\right]^{3}$

$$
\left.+\mathrm{k}_{\mathrm{Me}, 4} /\left[\mathrm{H}^{+}\right]^{4}+\mathrm{k}_{\mathrm{MHP}}\left[\mathrm{PO}_{4}^{3-}\right]\left[\mathrm{H}^{+}\right]^{2} /\left(\mathrm{k}_{\mathrm{p}, 2} \mathrm{k}_{\mathrm{p}, 3}\right)\right\}
$$

where:

$\mathrm{AM}_{\mathrm{P}}$ and $\mathrm{AM}_{\mathrm{Me}}$ are the atomic masses of phosphorus and the metal (in $\mathrm{g} / \mathrm{mol}$ )

$\mathrm{k}_{\mathrm{p}, 1}, \mathrm{k}_{\mathrm{p}, 2}, \ldots \ldots \mathrm{k}_{\mathrm{MHP}}$ etc. are defined in Table 1 .

[Note: Briggs (1996) appears to have used both the terms Me* and $\mathrm{Me}_{T}$ to describe the same residual equilibriummetal concentration].

In Eq. 17, $\mathrm{Me}_{\mathrm{T}}$ represents the soluble metal concentration (including ion pairs) in equilibrium with the precipitates (metal hydroxide and/or metal (hydroxy) phosphate). Similarly Briggs (1996) defined $\mathrm{P}_{\mathrm{Pres}}$ (Eq. 16) as the minimum equilibrium phosphorus concentration with both precipitates present. This represents the absolute minimum phosphorus residual that can be achieved at any given $\mathrm{pH}$. Hence, the orthoP residual concentration $\left(\mathrm{P}_{\mathrm{r}}\right)$ predicted by Eq. 13 must never be less than $\mathrm{P}_{\mathrm{P} \text { res }}$. Mathematically this condition can be satisfied by the expression:

$$
\mathrm{P}_{\mathrm{P}}^{*}=\max \left\{\mathrm{a}_{1} \cdot \mathrm{P}_{\mathrm{P} 0} \cdot \mathrm{e}^{-\mathrm{a}_{2} \cdot\left(\mathrm{Me}_{0} / \mathrm{P}_{\mathrm{P}}\right)}, \mathrm{P}_{\mathrm{P} \text { res }}\right\}
$$

Having solved for $\mathrm{P}_{\mathrm{P}} *$ and $\mathrm{Me}_{\mathrm{T}}\left(=\mathrm{Me}^{*}\right)$ using Eqs. 14 through 18, it is possible to calculate the amounts of metal hydroxy-phosphate $\left(\mathrm{X}_{\mathrm{MeP}}\right)$ and metal hydroxide $\left(\mathrm{X}_{\mathrm{MeH}}\right)$ precipitate formed though mass balances (Briggs, 1996):

$$
\begin{aligned}
& \mathrm{X}_{\mathrm{MeP}}=\mathrm{MW}_{\mathrm{MeP}} / \mathrm{MW}_{\mathrm{P}} \cdot\left(\mathrm{P}_{\mathrm{P} 0}-\mathrm{P}_{\mathrm{P}}^{*}\right) \\
& \mathrm{X}_{\mathrm{MeH}}=\mathrm{MW}_{\mathrm{MeH}} / \mathrm{MW}_{\mathrm{Me}}\left(\mathrm{Me}_{0}-\mathrm{r} \cdot \mathrm{MW}_{\mathrm{Me}} / \mathrm{MW}_{\mathrm{P}} \cdot\left(\mathrm{P}_{\mathrm{P} 0}-\mathrm{P}_{\mathrm{P}}^{*}\right)-\mathrm{Me}^{*}\right)
\end{aligned}
$$

where:

$\mathrm{P}_{\mathrm{P} 0}$ and $\mathrm{P}_{\mathrm{P}} *$ (in $\mathrm{mgP} / \ell$ ) are defined above

MW implies molecular weight $(\mathrm{g} / \mathrm{mol})$

$\mathrm{Me}_{0}=$ initial metal concentration (dosed) (in mg Me/l)

$\mathrm{X}_{\mathrm{MeP}}=$ concentration of metal hydroxy-phosphate formed $(\mathrm{mg} / \mathrm{l})$

$\mathrm{X}_{\mathrm{MeH}}=$ concentration of metal hydroxide formed $(\mathrm{mg} / \ell)$

\section{pH, alkalinity and equilibrium considerations}

Briggs (1996) derived equilibrium relationships for pHand alkalinity in order to predict the effect of chemical addition on these parameters

TABLE 1

and constants used by Briggs (1996)

\begin{tabular}{l|c|c|c|} 
& $\begin{array}{c}\text { Equilibrium } \\
\text { constant }\end{array}$ & $\begin{array}{c}\mathbf{p K} \\
\mathbf{A l}^{3+} \text { salts }\end{array}$ & $\begin{array}{c}\mathbf{p K} \\
\mathbf{F e}^{3+} \text { salts }\end{array}$ \\
\hline$+\mathrm{H}^{+}$ & $\mathrm{k}_{\mathrm{p}, 1}$ & 2.1 & 2.1 \\
$+\mathrm{H}^{+}$ & $\mathrm{k}_{\mathrm{p}, 2}$ & 7.2 & 7.2 \\
$\mathrm{MeH}_{2} \mathrm{PO}_{4}^{2+}$ & $\mathrm{k}_{\mathrm{p}, 3}$ & 12.3 & 12.3 \\
$\mathrm{e}(\mathrm{OH})^{2+}+\mathrm{H}^{+}$ & $\mathrm{k}_{\mathrm{MHP}}$ & -6.0 & -21.5 (Note 1) \\
$\mathrm{Me}(\mathrm{OH})_{2}^{+}+2 \mathrm{H}^{+}$ & $\mathrm{k}_{\mathrm{Me}, 1}$ & 5.0 & 3.0 \\
$\mathrm{Me}(\mathrm{OH})_{3}^{0}+3 \mathrm{H}^{+}$ & $\mathrm{k}_{\mathrm{Me}, 2}$ & 8.7 & 6.4 \\
$\mathrm{Me}(\mathrm{OH})_{4}{ }^{-}+4 \mathrm{H}^{+}$ & $\mathrm{k}_{\mathrm{Me}, 3}$ & 15.2 & 13.5 \\
& $\mathrm{k}_{\mathrm{Me}, 4}$ & 23.3 & 23.5 \\
\hline
\end{tabular}

ote 1: During model testing Briggs (1996) found that the $\mathrm{k}_{\mathrm{MHP}}$ constant required adjustment to $\mathrm{pK}=-17.5$. This adjustment was related to the use of the solubility product for $\mathrm{Fe}(\mathrm{OH})_{3}$ by Briggs (1996) rather than that for FeOOH used by Luedecke et al., 1989].

and to link the equilibrium $\mathrm{pH}$ to the residual orthoP and metal concentrations. However, for simplicity, in this paper the model considerations will be confined to those under the assumed condition of constant pH. Examination of the pilot plant data (De Haas et al., $2000 \mathrm{a}, \mathrm{b}$; 2001) shows that in most cases the reactor $\mathrm{pH}$ fluctuated in a relatively small range close to neutral (ca. 7.2 to 7.6). The reasons for this were that the influent alkalinity was usually supplemented with bicarbonate alkalinity (except in cases where the effect of withdrawal of this supplement was tested), and the metal dosages used were relatively small. The highest metal dose was ca. $60 \mathrm{mg} / \mathrm{l}$ as $\mathrm{FeCl}_{3}$, which would have given a theoretical alkalinity loss of $55 \mathrm{mg} / \ell$ as $\mathrm{CaCO}_{3}$, compared to the alkalinity supplement of $100 \mathrm{mg} / \ell$ as $\mathrm{CaCO}_{3}$.

\section{Rate equations for precipitation/dissociation}

The chemical solids produced in simultaneous precipitation systems will accumulate in the system as inert solids. However, if soluble concentrations of $\mathrm{P}$ or metal ion are reduced below the minimum equilibrium concentrations at the prevailing $\mathrm{pH}$, then metal hydroxyphosphate and/or metal hydroxide will dissociate to maintain equilibrium residuals. Accordingly, Briggs (1996) proposed rate equations for dissociation of both the precipitates. Also, a (reverse) rate equation was proposed for metal hydroxide formation. However, no rate equation for metal hydroxy-phosphate formation was proposed (Briggs, 1996). This implies that in the chemical model of Briggs, metal hydroxy-phosphate formation is assumed to be instantaneous. No allowance is made for dynamic formation of metal hydroxy-phosphate in response to metal ion potentially becoming available through the dissociation of metal hydroxide, for example. The possible implications of this are discussed later in this paper when evaluating the Briggs (1996) model.

The rate equation for metal hydroxy-phosphate dissociation (Briggs, 1996) is given in Eq. 21. It should be noted that two switching functions are included in Eq. 21: one to switch off dissociation when there is no precipitate $\left(\mathrm{X}_{\mathrm{MeP}} /\left\{\mathrm{K}_{\mathrm{s}, \mathrm{diss}}+\mathrm{X}_{\mathrm{MeP}}\right\}\right)$ and the other to switch dissociation on when the actual residual $\mathrm{P}$ concentration $\left(\mathrm{P}_{\mathrm{P}}\right)$ drops below the minimum equilibrium $\mathrm{P}$ concentration $\left(\mathrm{P}_{\mathrm{P} \text { res }}\right)$ at a given $\mathrm{pH}$ :

$$
\mathrm{r}_{1}=0.5 \cdot \mathrm{k}_{\mathrm{p}} \cdot\left[\left(\mathrm{P}_{\mathrm{Pres}}-\mathrm{P}_{\mathrm{P}}\right)+\left|\mathrm{P}_{\mathrm{Pres}}-\mathrm{P}_{\mathrm{P}}\right|\right] \cdot\left(\mathrm{X}_{\mathrm{MeP}} /\left\{\mathrm{K}_{\mathrm{s}, \mathrm{diss}}+\mathrm{X}_{\mathrm{MeP}}\right\}\right)
$$


where:

$\mathrm{K}_{\mathrm{s} \text { diss }}=$ switching function constant (mg/l MeP)

$\mathrm{k}_{\mathrm{p}}=$ metal hydroxy-phosphate dissociation rate constant $\left(\mathrm{d}^{-1}\right)$

When $\mathrm{P}_{\mathrm{P}}<\mathrm{P}_{\text {Pres }}$, dissociation is turned on and Eq. 21 reduces to:

$$
\mathrm{r}_{1}=\mathrm{k}_{\mathrm{p}} \cdot\left(\mathrm{P}_{\mathrm{P} \text { res }}-\mathrm{P}_{\mathrm{P}}\right) \cdot\left(\mathrm{X}_{\mathrm{MeP}} /\left\{\mathrm{K}_{\mathrm{s}, \mathrm{diss}}+\mathrm{X}_{\mathrm{MeP}}\right\}\right)
$$

However, Briggs (1996) pointed out that this will rarely occur and may be expected only at high metal:P dosage ratios; alternatively, in systems exhibiting biological excess $\mathrm{P}$ removal, high organic loading can result in low effluent $\mathrm{P}$ concentrations, due influent $\mathrm{P}$ becoming limiting.

Similarly to Eq. 21, Briggs (1996) proposed rate equations for both metal hydroxide dissociation and precipitation:

For precipitation:

$\mathrm{r}_{2}=0.5 \mathrm{k}_{\mathrm{m}}\left[\left(\mathrm{Me}-\mathrm{Me}^{*}\right)+\left|\mathrm{Me}-\mathrm{Me}^{*}\right|\right]$

For dissociation:

$\mathrm{r}_{3}=0.5 \mathrm{k}_{\mathrm{m}}\left[\left(\mathrm{Me}^{*}-\mathrm{Me}\right)+\left|\mathrm{Me} \mathrm{e}^{*}-\mathrm{Me}\right|\right] \cdot\left(\mathrm{X}_{\mathrm{MeH}} /\left\{\mathrm{K}_{\mathrm{s}, \mathrm{diss}}+\mathrm{X}_{\mathrm{MeH}}\right\}\right)$

where:

$\mathrm{k}_{\mathrm{m}}$ is the metal hydroxide precipitation/dissociation rate constant $\left(\mathrm{d}^{-1}\right)$

$\mathrm{Me}$ is the actual metal ion concentration ( $\mathrm{mg} \mathrm{Me} / \ell$ )

$\mathrm{Me}^{*}$ is the minimum equilibrium metal ion concentration at a given $\mathrm{pH}(\mathrm{mg} \mathrm{Me} / \ell)$.

Examination of Eqs. 22 and 23 shows that precipitation $\left(r_{2}\right)$ will be turned on when $\mathrm{Me}>\mathrm{Me}^{*}$ and off when $\mathrm{Me}<\mathrm{Me}^{*}$, whereas the converse will be true for dissociation $\left(r_{3}\right)$. Dissociation will also be turned off when no metal hydroxide precipitate $\left(\mathrm{X}_{\mathrm{MeH}}\right)$ is left in the system.

Due to the rapid kinetics of phosphate dissociation, Briggs (1996) assumed that the reaction would be virtually complete after approx. 30 seconds. Phosphate dissociation was modelled in the concentration range ca. 0.5 to $5 \mathrm{mgP} / \ell$ (a reasonable estimate for most domestic wastewaters), and a default value of $\mathrm{k}_{\mathrm{p}}=0.1 \mathrm{sec}^{-1}$ (or $8640 \mathrm{~d}^{-1}$ ) was accepted. Furthermore, Briggs (1996) assumed that the kinetics of metal hydroxide precipitation/ dissociation would be similar to that for metal phosphate dissociation. Hence, the default value for $\mathrm{k}_{\mathrm{m}}$ was also set to $8640 \mathrm{~d}^{-1}$. Overall, the precise calibration of these rate constants was considered to be unimportant since the chemical precipitation/ dissociation reactions are much faster than most of the biological processes of activated sludge.

\section{Rate equations for adsorption/desorption}

Briggs (1996) pointed out that in terms of the Elovich equation (Eq 8) there is no limit to adsorption since no maximum adsorption capacity is defined. That is, even if a maximum adsorption capacity $\left(\mathrm{q}_{\mathrm{m}}\right)$ exists, the rate of change of $\mathrm{q}$ with time will still be positive, implying that $\mathrm{q}$ will continue to increase. Similarly, as $\mathrm{P}$ residuals reach zero, phosphate adsorption can still occur in terms of Eq. 8, which is impossible. As one possible solution to these problems, Briggs (1996) incorporated switching functions for adsorption capacity and phosphate residual into Eq. 8, and produced generalised forms of the equation for adsorption onto each of the precipitates, namely metal hydroxy-phosphate and metal hydroxide (Eqs. 24 and 25 respectively):

$$
\begin{aligned}
\mathrm{r}_{4}= & \mathrm{a}_{\mathrm{p}} \cdot \mathrm{X}_{\mathrm{MeP}} \cdot \exp \left\{-\mathrm{b}_{\mathrm{P}} \cdot \mathrm{q}_{\mathrm{P}}\right\} \cdot\left[\mathrm{P}_{\mathrm{P}} /\left(\mathrm{K}_{\mathrm{sP}}+\mathrm{P}_{\mathrm{P}}\right)\right] \cdot\left[\left(\mathrm{q}_{\mathrm{mP}}-\mathrm{q}_{\mathrm{P}}\right) /\left(\mathrm{K}_{\mathrm{sq}}\right.\right. \\
& \left.+\left(\mathrm{q}_{\mathrm{mP}}-\mathrm{q}_{\mathrm{p}}\right)\right]
\end{aligned}
$$

$$
\begin{aligned}
\mathrm{r}_{5}= & \underset{\mathrm{M}}{\mathrm{a}_{\mathrm{M}}} \cdot \mathrm{X}_{\mathrm{MeH}} \cdot \exp \left\{-\mathrm{b}_{\mathrm{M}} \cdot \mathrm{q}_{\mathrm{M}}\right\} \cdot\left[\mathrm{P}_{\mathrm{P}} /\left(\mathrm{K}_{\mathrm{sP}}+\mathrm{P}_{\mathrm{P}}\right)\right] \cdot\left[\left(\mathrm{q}_{\mathrm{mM}}-\mathrm{q}_{\mathrm{M}}\right) /\right. \\
& \left(\mathrm{K}_{\mathrm{sq}}+\left(\mathrm{q}_{\mathrm{mM}}-\mathrm{q}_{\mathrm{M}}\right)\right]
\end{aligned}
$$

where:

$\mathrm{a}_{\mathrm{p}}$ and $\mathrm{a}_{\mathrm{M}}=$ adsorption rate constants ( $\left.\mathrm{mgP} /[\mathrm{mgX} . \mathrm{d}]\right)$

$\mathrm{b}_{\mathrm{P}}$ and $\mathrm{b}_{\mathrm{M}}=$ constants related to activation energy for adsorption ( $\mathrm{mgX} / \mathrm{mgP})$

$\mathrm{q}_{\mathrm{p}}=$ mass of phosphate adsorbed per unit mass metal hydroxy-phosphate precipitate $\left(\mathrm{mgP} / \mathrm{mgX}_{\mathrm{MeP}}\right)$

$\mathrm{q}_{\mathrm{M}}=$ mass of phosphate adsorbed per unit mass metal hydroxide precipitate $\left(\mathrm{mgP} / \mathrm{mgX}_{\mathrm{MeH}}\right)$

$\mathrm{q}_{\mathrm{mP}}=$ maximum adsorption capacity for metal hydroxyphosphate $\left(\mathrm{mgP} / \mathrm{mgX}_{\mathrm{MeP}}\right)$

$\mathrm{q}_{\mathrm{mM}}=$ maximum adsorption capacity for metal hydroxide $\left(\mathrm{mgP} / \mathrm{mgX}_{\mathrm{MeH}}\right)$

$\mathrm{K}_{\mathrm{sq}}=$ adsorptive capacity switching function constant $(\mathrm{mgP} / \mathrm{mgX})$

$\mathrm{K}_{\mathrm{sP}}=$ phosphorus switching function constant (mgP/ $)$

Since the composition of the chemical solids present in the system may vary, the adsorptive capacity of the solids may vary. The phosphate adsorptive capacity would be directly correlated to the number of hydroxyl groups available for exchange. Uncertainty over the composition of the solids present in the system makes it difficult to quantify the constants $\mathrm{q}_{\mathrm{mP}}$ and $\mathrm{q}_{\mathrm{mM}}$. These constants would need to be empirically determined or based on a hypothetical precipitate composition. In the case of adsorption onto metal hydroxy-phosphate, it is possible to state that no adsorption will occur when $r=1$ (Eq. 9) since no hydroxyl groups will be available on the precipitate. The constants $\mathrm{a}_{\mathrm{p}}$ and $\mathrm{q}_{\mathrm{mP}}$ should therefore be set to zero when $r=1$ in this case (Briggs, 1996).

During dissociation of precipitate, any adsorbed phosphate would be desorbed. Therefore, Briggs (1996) modelled the desorption rate as a simple proportion of the rate of dissociation, based on the mass of phosphate adsorbed per unit precipitate:

$$
\begin{aligned}
& \mathrm{r}_{6}=\mathrm{r}_{1} \mathrm{q}_{\mathrm{P}}=\mathrm{r}_{1} \mathrm{P}_{\mathrm{aP}} / \mathrm{X}_{\mathrm{MeP}} \\
& \mathrm{r}_{7}=\mathrm{r}_{3} \mathrm{q}_{\mathrm{M}}=\mathrm{r}_{3} \mathrm{P}_{\mathrm{aM}} / \mathrm{X}_{\mathrm{MeH}}
\end{aligned}
$$

where $\mathrm{P}_{\mathrm{aP}} / \mathrm{X}_{\mathrm{MeP}}$ and $\mathrm{P}_{\mathrm{aM}} / \mathrm{X}_{\mathrm{MeH}}$ are the concentrations of phosphate adsorbed per unit mass metal hydroxy-phosphate and metal hydroxide, respectively.

\section{Calibration and testing of the Briggs model}

Briggs (1996) incorporated the chemical model outlined above into a dynamic biological model of activated sludge systems (similar to the IAWQ/IAWPRC ASM Model No. 1). In order to calibrate the chemical model, Briggs commenced with estimates of the key parameters based on literature results, followed by site-specific calibration to a full-scale wastewater works using simultaneous alum addition. In order to evaluate the suitability of the model for application to the results of this study, it is instructive to examine the calibration steps reported by Briggs (1996).

\section{Stoichiometry for metal (hydroxy) phosphate precipitation}

Equation 13 contains two constants, namely $a_{1}$ and $a_{2} \cdot a_{1}$ is essentially a correction factor to account for the minimum dosage required to initiate precipitation (Briggs, 1996). As noted above, the value of $a_{1}$ may be assumed to be unity for simultaneous 
precipitation processes on the basis that the concentration of soluble organics which may complex the added metal ions would be expected to be low in (or after) the aeration basin.

The second constant $\left(a_{2}\right)$ relates to the stoichiometry of precipitation. Briggs (1996) derived values for $a_{2}$ by fitting Eq. 13 to actual reported precipitation data and model results (e.g. that of Luedecke et al., 1989) and obtained values of 1.40 to 1.42 for dosing with aluminium ions and 0.43 to 0.59 for ferric ions. Furthermore, the data of Luedecke et al. (1989) suggested that ferric chloride shows a "lag" at low metal:P ratios, with $\mathrm{a}_{1}=1.3$ giving the best fit for ferric chloride. Briggs (1996) accepted a value of $\mathrm{a}_{1}=1$ for alum.

Fig. 3 illustrates the effect that $a_{1}$ theoretically would have on Pp* using Eq. 13 from the Briggs model. In this study (De Haas et al., $2000 \mathrm{~b}$ ) ferric chloride doses in the range up to $\sim 20 \mathrm{mg} / \ell$ as $\mathrm{Fe}$ are likely to be realistic for simultaneous dosing to biological excess phosphorus removal (BEPR) plants. From Fig. 3 it is apparent that the uncertainty over $a_{1}$ is likely to be significant for modelling chemical precipitation under these conditions since it falls into the range where the "lag" effect may be present. Briggs (1996) assumed $a_{1}=1$ for alum and only reported model testing for actual plant data with alum dosing, with the result that the $a_{1}$ value for ferric ions was not further investigated.

\section{Equilibrium residuals}

In the model of Briggs (1996), $\left[\mathrm{PO}_{4}^{3-}\right]$ is first calculated from solubility products and $\mathrm{pH}$ using Eq. 15 . The total equilibrium phosphate residuals $\left(\mathrm{P}_{\text {Pres }}\right)$ are then estimated as a function of $\mathrm{pH}$ using Eq. 16 and an accepted set of complexes (ion pairs) and equilibrium constants (e.g. those in Table 1, presented by Briggs, 1996). From $P_{\text {Pres }}$, the actual residual phosphorus concentration $\left(\mathrm{P}_{\mathrm{P}}{ }^{*}\right)$ for a given metal dose can be calculated using Eq. 18 and hence the amount of metal phosphate precipitate determined from Eq. (19). Similarly for the metal, Eqs. 14, 17 and 20 are solved sequentially to calculate the metal hydroxide precipitate.

In the calculations above, the actual $\mathrm{P}$ residual $\left(\mathrm{P}_{\mathrm{P}}{ }^{*}\right)$ is the sum of a number of phosphate weak acid/base species: $\mathrm{PO}_{4}^{3-} / \mathrm{HPO}_{4}^{2-} /$ $\mathrm{H}_{2} \mathrm{PO}_{4}^{-} / \mathrm{H}_{3} \mathrm{PO}_{4}$ and any soluble metal-phosphate $(\mathrm{MeP})$ complexes that may be present (from Eq. 16). The relative amount of each MeP ion pair complex present in solution is dependent on the solubility products for the chemical precipitates (which control $\mathrm{PO}_{4}^{3-}$ and $\mathrm{Me}^{3+}$ as a function of $\mathrm{pH}$ ), as well as on the ion-pair equilibrium constants and the equilibrium constants for the phosphate-weak acid/base species. Prediction of the equilibrium $P$ residuals is dependent on the choice of solubility products and equilibrium constants. Table 1 summarises the equilibrium constants and Table 2 the solubility data obtained from literature sources by Briggs (1996).

In his model, for both alum and ferric salts, Briggs (1996) opted to use the simple $\mathrm{MePO}_{4}$ solubility products rather than those of the more complex metal hydroxy-phosphate, on the basis that similar (low) phosphate residuals are predicted using Eqs. 14 and 15 (appropriately modified for $\mathrm{MePO}_{4}$ ) as those reported by Luedecke et al. (1989).

According to Briggs (1996), the $\mathrm{MePO}_{4}$ solubility product was "adjusted slightly" (Table 2) to provide residual phosphate predictions similar to those published in the literature. Similarly, the $\mathrm{Me}(\mathrm{OH})_{3}$ solubility product was "manipulated about the average value" (presented in Table 2) to provide metal equilibrium residuals of approximately $0.1 \mathrm{mg} / \mathrm{l}$ in the range 6.5 to 7.5 to mimic residuals reported in the literature. The need for manipulations of this kind by Briggs (1996) illustrates that literature values for the various constants in the chemical model cannot be applied directly in all

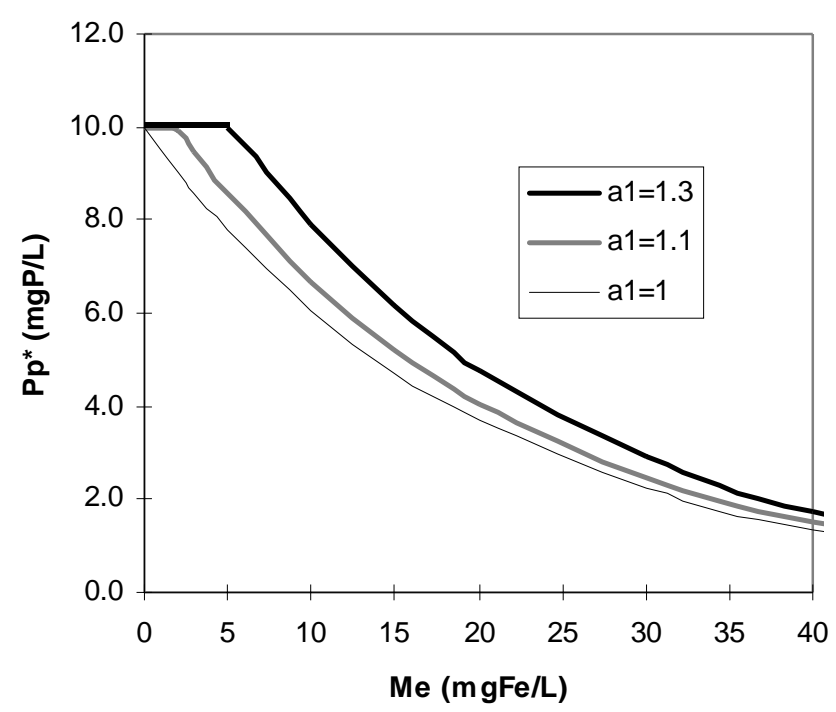

Figure 3

Theoretical effect of changing $a_{1}$ from 1 to 1.3 on $P$ residual predicted from Eq. 13 for conditions in which $P_{p 0}=10 \mathrm{mgP} / \mathrm{l}$ and $a_{2}=0.5$ for ferric chloride dosing, according to Briggs (1996). Note: $a_{1}$ and $a 2$ represent $a_{1}$ and $a_{2}$ in Fig. 3.

cases; a degree of calibration is required, based on actual experimental results for the particular system under study.

\section{lonic strength effects}

Briggs (1996) did not report the use of apparent solubility products or apparent equilibrium constants in his work, to take ionic strength effects into account. Apparent constants can be derived from the literature data in Tables 1 and 2 using Debye-Hückel theory (Loewenthal and Marais, 1976). The resultant values are given in Tables 3 and 4 respectively. [In these derivations, the ionic strength of real solutions corresponding to the experimental system, must be assumed. For the purposes of deriving the apparent constants here, an ionic strength (m) of 0.01 was assumed. This corresponds to a real solution with a TDS of approximately $400 \mathrm{mg} / \mathrm{h}$, which was representative of the effluent TDS for Darvill Wastewater Works in this study].

The effect of using the apparent constants is shown in Figs. 4a $\& 4 \mathrm{~b}$ for alum and ferric salts respectively.

From Figs. $4 \mathrm{a} \& \mathrm{~b}$ it can be seen that the effect of correcting for ionic strength effects by using apparent solubility products and equilibrium constants is to increase the residual orthoP and metal concentrations. However, the changes are relatively small. The biggest difference found (Fig. 4a) was for alum at $\mathrm{pH} 7.8$, giving a change in $\mathrm{P}_{\text {Pres }}=2.7 \mathrm{mgP} / \ell$; at $\mathrm{pH} 6.8$ the change was only 0.04 $\mathrm{mgP} / \ell$. For ferric salt the corresponding changes ranged from approx. $0.1 \mathrm{mgP} / \ell$ (pH 6.8) to $0.4 \mathrm{mgP} / \ell$ ( $\mathrm{pH} 7.8$ ). The changes in soluble metal residual were negligible for alum $(0.01 \mathrm{mg} / \ell$ as $\mathrm{Al})$ and minor for ferric salt $(<0.14 \mathrm{mg} / \ell$ as Fe $)$. On the basis of Figs. $4 \mathrm{a}$ $\& b$, the need to correct from theoretical to apparent solubility product and equilibrium constant data does not appear to be critical, but should not be ignored, particularly at higher ionic strength.

\section{Adsorption kinetics and stoichiometry}

The Elovich-type equations used by Briggs (1996) for describing phosphate adsorption to metal hydroxy-phosphate and metal hydroxide were given respectively in Eqs. 23 and 24. In these 


\begin{tabular}{|c|c|c|c|c|}
\hline \multicolumn{5}{|c|}{$\begin{array}{l}\text { TABLE } 2 \\
\text { Solubility product data for metal phosphate and metal hydroxide } \\
\text { precipitates from literature sources quoted by Briggs (1996) }\end{array}$} \\
\hline Precipitate & $\begin{array}{c}\mathrm{pK}_{\mathrm{sp}} \text { range in } \\
\text { literature }\end{array}$ & $\begin{array}{c}\text { Average } \\
\text { pKsp }\end{array}$ & $\begin{array}{l}\mathrm{pK}_{\mathrm{sp}} \text { value(s) } \\
\text { adopted by } \\
\text { Briggs }\end{array}$ & Notes \\
\hline $\begin{array}{l}\mathrm{AlPO}_{4} \\
\left.\mathrm{Al}_{1.4} \mathrm{PO}_{4(} \mathrm{OH}\right)_{1.2} \\
\mathrm{Al}(\mathrm{OH})_{3}\end{array}$ & $\begin{array}{l}20 \text { to } 21 \\
32.2 \text { to } 34 \\
\quad 33\end{array}$ & $\begin{array}{c}20.3 \\
32.5 \\
33\end{array}$ & $\begin{array}{l}21.18 \text { to } 22.2 \\
\text { Not used } \\
\quad 32.3\end{array}$ & $\begin{array}{c}\text { Notes } 1,2 \\
- \\
\text { Note } 3\end{array}$ \\
\hline $\begin{array}{l}\mathrm{FePO}_{4} \\
\mathrm{Fe}_{2.5} \mathrm{PO} 4(\mathrm{OH})_{4.5} \\
\mathrm{FeOOH} \\
\mathrm{Fe}(\mathrm{OH})_{3}\end{array}$ & $\begin{array}{c}28 \\
96.7 \\
-0.5 \\
38 \text { to } 38.6\end{array}$ & $\begin{array}{l}28 \\
96.7 \\
-0.5 \\
38.2\end{array}$ & $\begin{array}{l}28.75 \\
\text { Not used } \\
\text { Not used } \\
38.2\end{array}$ & $\begin{array}{l}\text { Note } 4 \\
- \\
\text { Note } 5 \\
\quad-\end{array}$ \\
\hline \multicolumn{5}{|c|}{$\begin{array}{l}\text { Note } 1 \text { Galarneu and Gehr (1997) reported a value of } 18.24 \text { for the } \mathrm{pK}_{\mathrm{sp}} \text { of } \mathrm{AlPO}_{4} \text {. However, } \\
\text { using this value in the model proposed by Briggs (1996) leads to the conclusion that the } \\
\text { minimum equilibrium orthoP concentration would be } 2244 \mathrm{mgP} / \ell \text { for aluminium } \\
\text { phosphate precipitation, which appears erroneous. In the light of this, a value of at least } \\
20 \text { for this constant seems more reasonable. }\end{array}$} \\
\hline Note 2 After testi & $\begin{array}{l}\text { memical model ag } \\
\text { red in order to dec }\end{array}$ & $\begin{array}{l}\text { st actual dat } \\
\text { 6) found the } \\
\text { se predicted }\end{array}$ & $\begin{array}{l}\text { om an activated sl } \\
\text { ne a pK } \text { spalue of }_{\text {vilibrium orthoP }}\end{array}$ & $\begin{array}{l}\text { lge plant with } \\
.0 \text { to } 22.2 \text { for } \\
\text { iduals }\end{array}$ \\
\hline Note 3 & $\begin{array}{l}\text { nipulated the } \mathrm{pK}_{\mathrm{sp}} \\
\text { alues reported in } \mathrm{t}\end{array}$ & $\begin{array}{l}\mathrm{Al}(\mathrm{OH})_{3} \text { va } \\
\text { literature. }\end{array}$ & slightly to match & edicted metal \\
\hline Note 4 Although & $\begin{array}{l}\text { (1996) did not state } \\
\text { ved by trial-and-er } \\
\text { nted by Briggs ( } 19\end{array}$ & $\begin{array}{l}\text { e final value } \\
\text { in the formu } \\
\text {. }\end{array}$ & $\begin{array}{l}\text { cepted for } \mathrm{pK}_{\mathrm{MeP}}(\mathrm{F} \\
\text { on of Fig. } 4 \mathrm{~b} \text { in or }\end{array}$ & $\begin{array}{l}\text { PO4), a value } \\
\text { r to match the }\end{array}$ \\
\hline $\begin{array}{l}\text { Note } 5 \text { The Brigg } \\
\text { model of }\end{array}$ & $\begin{array}{l}\text { model is based or } \\
\text { ke et al. (1989) wh }\end{array}$ & $\begin{array}{l}(\mathrm{OH})_{3} \text { as th } \\
\text { was based }\end{array}$ & $\begin{array}{l}\text { rm of ferric hydro } \\
\mathrm{FeOOH} \text {. }\end{array}$ & de, unlike the \\
\hline
\end{tabular}

\begin{tabular}{|c|c|c|c|}
\hline \multicolumn{4}{|c|}{$\begin{array}{l}\text { TABLE } 3 \\
\text { Apparent equilibrium constants derived from values reported by } \\
\text { Briggs (1996) for ionic strength }(\mathrm{m})=0.01 \text {. Compare with Table } 1 \text {. }\end{array}$} \\
\hline Reaction & $\begin{array}{l}\text { Apparent } \\
\text { equilibrium } \\
\text { constant }\end{array}$ & $\begin{array}{c}\text { pK' } \\
\mathbf{A}^{3+}{ }^{3+} \text { salts }\end{array}$ & $\begin{array}{c}\text { pK' } \\
\mathrm{Fe}^{3+} \text { salts }\end{array}$ \\
\hline 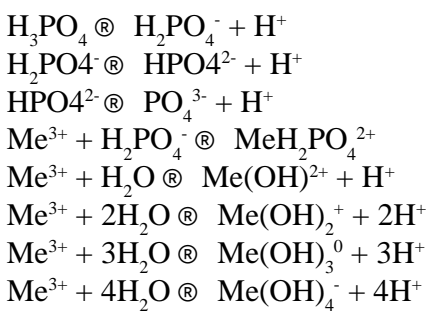 & 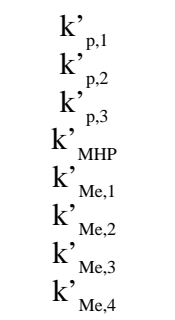 & $\begin{array}{c}2.05 \\
7.07 \\
12.07 \\
-5.72 \\
5.23 \\
9.06 \\
15.61 \\
23.66\end{array}$ & $\begin{array}{c}2.05 \\
7.07 \\
12.07 \\
-21.22(\text { Note } 1) \\
3.23 \\
6.76 \\
13.91 \\
23.86\end{array}$ \\
\hline $\begin{array}{l}\text { Using the value of }-17.5 \text { as } \\
\text { constant }\left(\mathrm{pk}_{\mathrm{MHP}}\right) \text { becomes }\end{array}$ & $\begin{array}{l}\text { nded by Briq } \\
22 .\end{array}$ & 96) (Table & , the apparent \\
\hline
\end{tabular}

equations, two main constants control the rate of adsorption: $\mathrm{a}_{\mathrm{m}}$ and $\mathrm{b}_{\mathrm{m}}$. According to Briggs (1996), $\mathrm{b}_{\mathrm{m}}$ affects mainly the slope of the rate curve (i.e. phosphate adsorbed versus time) during the initial phase of rapid adsorption when the ratio of adsorbed $\mathrm{P}$ to mass of precipitate is relatively small. $a_{m}$ affects the overall magnitude of the rate and is mainly relevant to the latter phase of slower adsorption. Data from the literature examined by Briggs (1996) suggested that the initial phase of rapid adsorption takes place in a matter of minutes, followed by a slower rate over several days. The equation proposed by Briggs (1996) (Eq. 23) was not able to model the first very rapid phase of adsorption over a time frame as brief as minutes, but predicts a rapid phase over the first day, followed by a declining rate over several days. This gave a fair approximation of the experimental data. The default values of $\mathrm{a}_{\mathrm{m}}$ and $\mathrm{b}_{\mathrm{m}}$ accepted by Briggs (1996) are given in Table 5, together with adsorption maxima $\left(\mathrm{q}_{\mathrm{mM}}\right)$ derived from literature data.

\section{Calibration to the Mid-Halton plant (by Briggs, 1996)}

Mid-Halton Wastewater Treatment Facility was reported by Briggs (1996) to consist of primary sedimentation followed by a fully aerobic step-feed activated sludge process in four stages with simultaneous alum addition in the last aeration tank. On the basis of average monthly data, the sludge age was calculated to vary from 2.1 to 6.6 days. Nitrification was not reported by Briggs (1996).

Briggs (1996) used an earlier version of the IAWQ (IAWPRC) model for COD, VSS and MLSS predictions (Henze et al., 1987). Phosphorus removal was based largely on the chemical model described above, without consideration of BEPR mechanisms. The only biological components affecting the chemical model are:

- Incorporation of a so-called "inert particulate P" fraction expressed on the basis of the influent $\left(\mathrm{P}_{\mathrm{xi}}\right)$ and modelled as a fixed $2.5 \%$ of the biomass VSS;

- Hydrolysis of particulate biodegradable organic $\mathrm{P}\left(\mathrm{P}_{\mathrm{e}}\right)$ to soluble biodegradable orthoP $\left(\mathrm{P}_{\mathrm{o}}\right)$ at the same rate as the hydrolysis of particulate (slowly) biodegradable COD determined by the IAWQ (IAWPRC) model;

- Hydrolysis of soluble biodegradable orthoP $\left(\mathrm{P}_{\mathrm{o}}\right)$ to orthoP $\left(\mathrm{P}_{\mathrm{p}}\right)$, modelled as a simple first order decay reaction with a constant rate of $\mathrm{k}_{\mathrm{rp}}$.

For Mid-Halton works, this approach was acceptable in that BEPR would not be expected in a completely aerobic activated

sludge process.

The modelling results for Mid-Halton were satisfactory. Briggs (1996) made the following observations from calibration to experimental data and a sensitivity analysis:

- The hydrolysis rate constant $\left(\mathrm{k}_{\mathrm{rp}}\right)$ for conversion of $\mathrm{P}_{\mathrm{o}}$ to orthoP $\left(\mathrm{P}_{\mathrm{p}}\right)$ needed to be increased in order to reduce the proportion of $\mathrm{P}_{\mathrm{o}}$ in the effluent. The effect of $\mathrm{k}_{\mathrm{rp}}$ on the effluent total $\mathrm{P}$ was small in absolute terms, but it did affect the relative proportions 


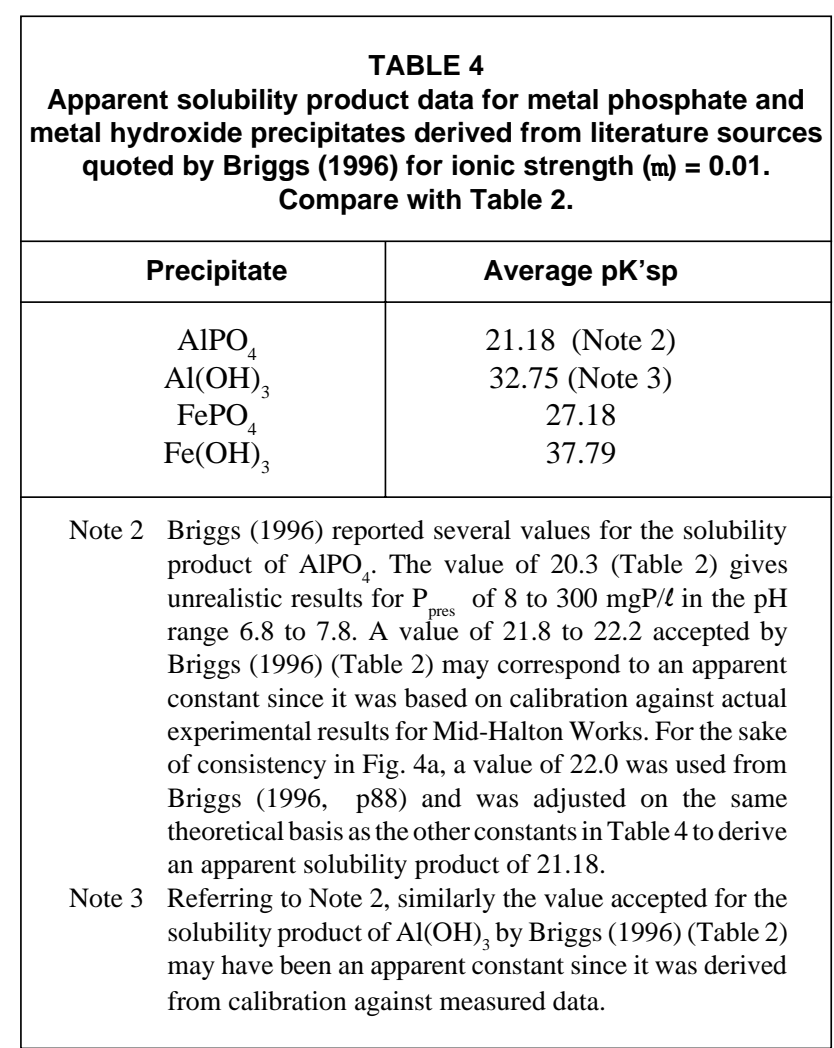

of $\mathrm{P}_{\mathrm{o}}$ and $\mathrm{P}_{\mathrm{P}}$ predicted in the effluent, especially since the observed orthoP residual was low $(<0.5 \mathrm{mgP} / \ell)$.

- The solubility product for $\mathrm{AlPO}_{4}$ had to be increased (to between 22.0 and 22.2) in order to reduce the equilibrium orthoP residual concentration predicted in relation to the actual plant data.

- As an alternative, the solubility product for aluminium hydroxide could have been decreased, thereby "freeing" more aluminium, which would precipitate phosphate and decrease the equilibrium orthoP residual concentration. However, this adjustment was not made since the equilibrium aluminium residuals were considered to be in the correct range (ca. $0.1 \mathrm{mg} / \ell$ as Al).

- Good prediction of VSS and TSS (or MLSS) concentrations was obtained over the range of sludge ages tested, noting that the masses of chemical sludge (metal phosphate and metal hydroxide precipitates) were included in the TSS predictions. [It appears that Briggs (1996) did not take into account that the measured ISS (determined by ashing) and calculated ISS are expected to differ for aluminium hydroxide. Assuming the formula of $\mathrm{Al}(\mathrm{OH})_{3}$ for residual aluminium hydroxide accumulating in the mixed liquor solids, upon ashing the hydroxide form may be expected to convert to the oxide form, $\mathrm{Al}_{2} \mathrm{O}_{3}$ :

$2 \mathrm{Al}(\mathrm{OH})_{3}{ }^{\circledR} \mathrm{Al}_{2} \mathrm{O}_{3}+3 \mathrm{H}_{2} \mathrm{O}$

Based on the change in molecular weight, a conversion factor $(102 / 156=0.65)$ should be applied for the calculated aluminium hydroxide contribution to ISS in the model. Since good agreement between the model calculations and measured TSS were reported by Briggs (1996), assuming a default molecular weight of 78 for $\mathrm{Al}(\mathrm{OH})_{3}$ contribution to the TSS, it appears that the magnitude of aluminium hydroxide contribution to the TSS was relatively small ( $\mathrm{ca}$. 6\%) for the test case of Mid-Halton Works].
TABLE 5

Default parameters for adsorption, according to Briggs (1996)

\begin{tabular}{|l|c|c|c|}
\hline Precipitate & $\begin{array}{c}\mathbf{a}_{\mathbf{m}} \\
\mathbf{m g P} / \mathbf{m g} \\
\mathbf{M e}(\mathbf{O H})_{3}\end{array}$ & $\begin{array}{c}\mathbf{b}_{\mathbf{m}} \\
\mathbf{m g ~} \mathbf{M e}(\mathbf{O H})_{3} / \\
\mathbf{m g P}\end{array}$ & $\begin{array}{c}\mathbf{q}_{\mathrm{mM}} \\
\mathbf{m g} \mathbf{P} / \mathbf{m g} \\
\mathbf{M e}(\mathbf{O H})_{3}\end{array}$ \\
\hline $\begin{array}{l}\text { Aluminium hydroxide } \\
\text { Ferric hydroxide }\end{array}$ & 0.15 & 169 & $2.0 * 10^{-4}$ \\
0.10 & 300 & $3.1 * 10^{-2}$ \\
\hline
\end{tabular}

- The waters of hydration of the chemical precipitates could affect TSS predictions to a significant extent. Briggs used the formula $\mathrm{AlPO}_{4} \cdot 2 \mathrm{H}_{2} \mathrm{O}$ for aluminium phosphate and $\mathrm{Al}(\mathrm{OH})_{3}$ for aluminium hydroxide. The aluminium hydroxide precipitate shows more impact on the TSS predictions than aluminium phosphate, for two reasons: Firstly, the relative proportion of metal phosphate to TSS in the system is small (limited by influent available P); and secondly, the relative contribution of each water of hydration to the molecular weight of the precipitate is greater for $\mathrm{AlOH}_{3}(\mathrm{MW}=78 \mathrm{~g} / \mathrm{mol})$ than for $\mathrm{AlPO}_{4}(\mathrm{MW}=$ $122 \mathrm{~g} / \mathrm{mol}$ ).

- Changing the phosphate precipitation efficiency parameter $\left(\mathrm{a}_{2}\right.$ in Eq. 18) only affects the orthoP residual concentration when the latter is not equilibrium-controlled (i.e. when $\mathrm{P}_{\mathrm{P}}^{*}>\mathrm{P}_{\text {Pres }}$ ). Increasing $a_{2}$ can result in lower orthoP residuals and can result in the system becoming equilibrium-controlled. Decreasing a has the opposite effect. Briggs (1996) found that the default value of $a_{2}=1.41$ for alum gave satisfactory agreement with observed effluent TP data.

- Results indicated that neither the adsorption nor the dissociation kinetics had any effect on model predictions. This was ascribed by Briggs to the low adsorption maximum for phosphorus onto the $\mathrm{Al}(\mathrm{OH})_{3}$ precipitate, $\mathrm{q}_{\mathrm{mM}}$. (Presumably, the mass of metal phosphate precipitate in the system was too small to be significant for phosphorus adsorption). Doubling or halving the value of $\mathrm{q}_{\mathrm{mM}}$ had no impact on the effluent orthoP (or TP) predictions since a very small default adsorptive capacity for the $\mathrm{Al}(\mathrm{OH})_{3}$ precipitate had been assumed (see Table 5). This implies that adsorption plays a minor role in the chemical model proposed by Briggs (1996).

\section{Evaluation of the Briggs (1996) model}

The model proposed by Briggs (1996) is useful in that it originates from first principles of phosphate equilibrium chemistry, with kinetic expressions introduced for certain processes (notably, organic phosphate hydrolysis; metal hydroxide precipitation and dissociation; metal hydroxy-phosphate dissociation; and adsorption). Although little attention has been paid in this review to the aspect of $\mathrm{pH}$, the equilibrium approach makes it possible to model the link between $\mathrm{pH}$ and phosphate precipitation directly a link that is important and well-established. However, the equilibrium approach introduces considerable complexity to the chemical model. It is necessary to examine whether this complexity can be justified. Sensitivity of the model predictions to certain key constants needs to be closely examined. Moreover, the potential difficulties of integrating an equilibrium chemical precipitation model of this type into the larger (and already complex) kinetic model for biological excess $\mathrm{P}$ removal in modified activated sludge systems needs to be considered. 
Figure 4a

Briggs (1996) chemical equilibrium precipitation model for alum (without adsorption) - Predicted minimum soluble ortho $P$ $\left(P_{\text {Pres }}\right)$ and aluminium $\left(\mathrm{Mee}_{T}\right.$ as $\left.\mathrm{A}^{\beta+}\right)$ residual concentrations with and without correction to apparent solubility product and equilibrium constant data.

Figure $4 b$ Briggs (1996) chemical equilibrium precipitation model for ferric chloride (without adsorption) Predicted minimum soluble orthoP $\left(P_{\text {Pres }}\right)$ and iron $\left(\mathrm{Me}_{\tau}\right.$ as $\left.\mathrm{Fe}^{3+}\right)$ residual concentrations with and without correction to apparent solubility product and equilibrium constant data.
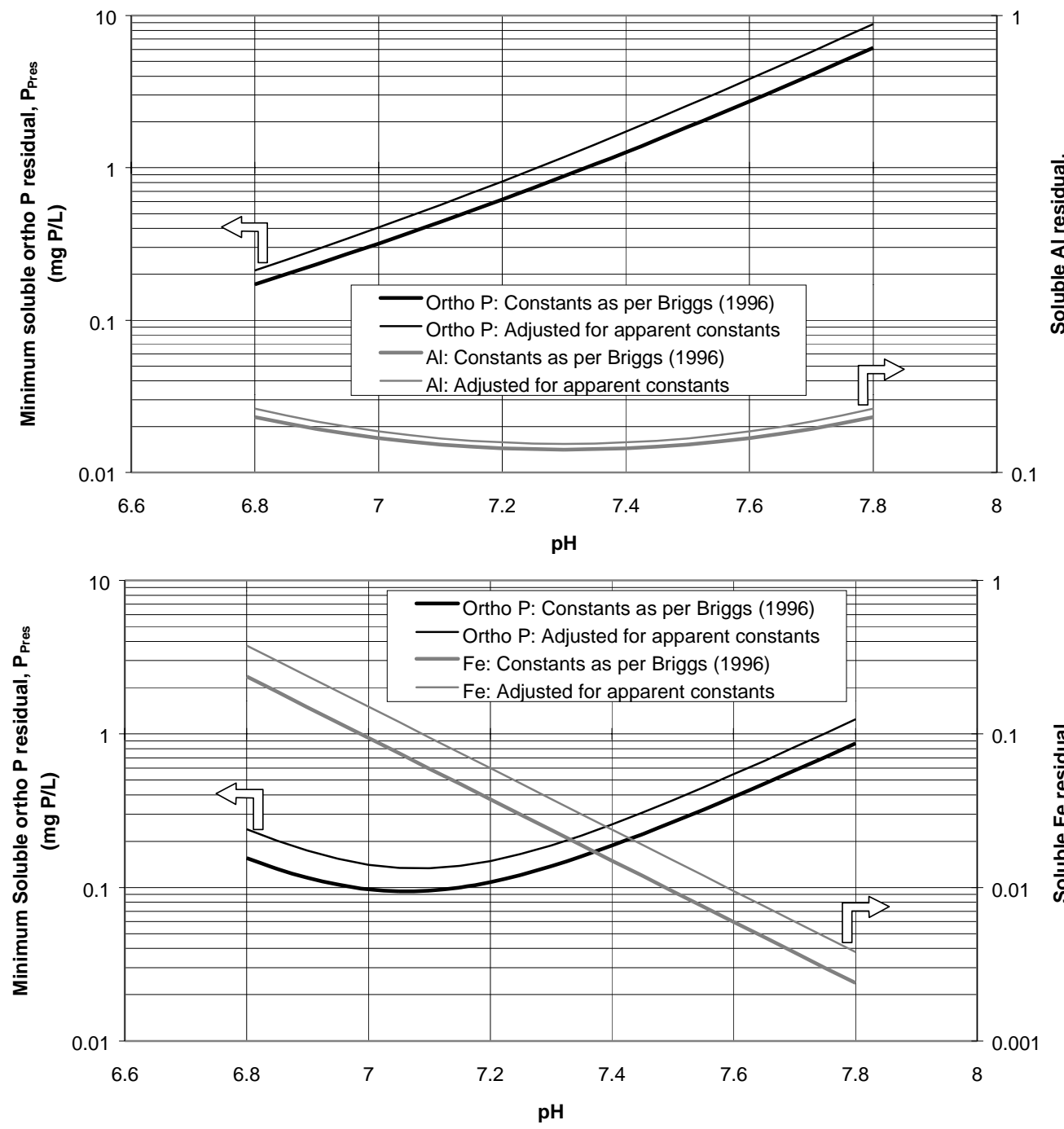

\section{Calibration and uncertainty over constants}

From the review of the work of Briggs (1996) it is apparent that the chemical model is very sensitive to a number of key constants. Uncertainty in the values for some of these constants presented a degree of difficulty and required calibration from actual plant data (Briggs, 1996). In this respect, an equilibrium model is no different from a kinetic model.

The key constants identified by Briggs (1996) which greatly influence the effluent orthoP (or TP) residual concentration were:

- The solubility product $\left(\mathrm{K}_{\mathrm{sp}}\right)$ for metal (hydroxy) phosphate.

- The solubility product $\left(\mathrm{K}_{\mathrm{sp}}\right)$ for metal hydroxide (only tested for the case of aluminium).

- The equilibrium constant $\left(\mathrm{k}_{\mathrm{MHP}}\right)$ for the metal phosphate complex $\left(\mathrm{MeH}_{2} \mathrm{PO}_{4}^{2+}\right)$ [Uncertainty over this constant was also identified by Luedecke et al. (1989)].

To this may be added that the equilibrium constants $\left(\mathrm{k}_{\mathrm{Me}, 1}\right.$ to $\left.\mathrm{k}_{\mathrm{Me}, 4}\right)$ for aluminium hydroxide ion pairs had a degree of inconsistency (refer to Appendix A). Accepting that inconsistency in the metalhydroxide ion pair equilibrium constant set may have partly caused the need to manipulate the aluminium hydroxide solubility product, the two constants that deserve further examination here are the metal hydroxy-phosphate solubility product $\left(\mathrm{K}_{\mathrm{MeP}}\right)$ and the metalphosphate complex equilibrium constant $\left(\mathrm{k}_{\mathrm{MHP}}\right)$.
In order to illustrate the effect of uncertainty in $\mathrm{k}_{\mathrm{MHP}}$, the case mentioned by Briggs (1996) for dosing with ferric ions is shown in Fig. 5. The range of uncertainty in the source data for $\mathrm{k}_{\mathrm{MHP}}$ was -20.5 to -22.7 (Luedecke et al., 1989). Briggs (1996) took the average $(-21.5)$ and corrected this to -17.5 to take into account the use of $\mathrm{Fe}(\mathrm{OH})_{3}$ instead of $\mathrm{FeOOH}$ as ferric hydroxide precipitate in the model. If the same approximation is applied to the range in data from Luedecke et al. (1989), $\mathrm{k}_{\mathrm{MHP}}$ values in the range -16.5 to -18.5 are obtained. The family of $P_{\text {pres }}$ curves shown in Fig. 5 may then be generated. From Fig. 5 it can be seen that the change in $\mathrm{k}_{\mathrm{MHP}}$ affects both the magnitude of $\mathrm{P}_{\text {pres }}$ in the range 0.05 to $1.1 \mathrm{mgP} / \ell$ (for the $\mathrm{pH}$ range 6.8 to 7.8 ) as well as the "optimum" $\mathrm{pH}$ at which the lowest $\mathrm{P}_{\text {pres }}$ is predicted. These changes will be significant for systems in which the $\mathrm{Me}_{\text {dosed }}: \mathrm{P}_{\text {initial }}$ ratio $\left(\mathrm{Me}_{0} / \mathrm{P}_{\mathrm{P} 0}\right)$ is relatively high such that the effluent residual orthoP concentration becomes equilibrium controlled (Eq. 18). Typically this could occur for many real situations in which the effluent orthoP (or total $\mathrm{P}$ ) discharge standard is $<1 \mathrm{mgP} / \ell$. The need for calibration of $\mathrm{k}_{\mathrm{MHP}}$ will therefore be most important if model accuracy of this order is required for such applications.

In order to illustrate the effect of uncertainty over the metal phosphate solubility product $\left(\mathrm{K}_{\mathrm{sp}}\right)$, the example of $\mathrm{AlPO}_{4}$ mentioned earlier (Table 1) may be examined in more detail. Two sources of data for $\mathrm{K}_{\mathrm{sp}}\left(\mathrm{AlPO}_{4}\right)$ were quoted by Briggs (1996), namely:

- $\mathrm{K}_{\mathrm{sp}}=20(\mathrm{CRC}, 1988)$

- $\mathrm{K}_{\mathrm{sp}}=21$ (Snoeyink and Jenkins, 1980). 
Ferric dosing: effect of uncertainty over $\mathbf{p k}_{\mathrm{MHP}}$ on $\mathbf{P}_{\text {pres }}$

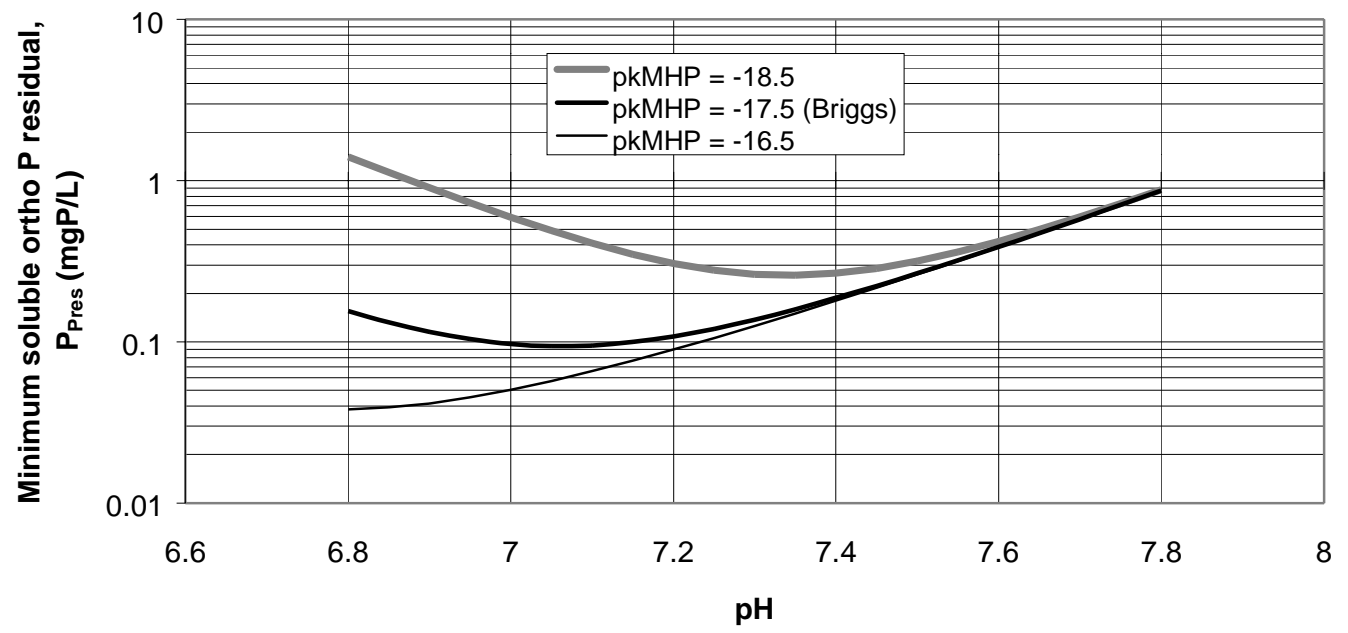

Figure 5

Effect of equilibrium constant for the metal phosphate complex $\mathrm{FeH}_{2} \mathrm{PO}_{4}^{2+}$ on minimum residual soluble orthoP $\left(P_{\text {Pres }}\right)$ concentrations for dosing with ferric salt, according to Briggs (1996) chemical equilibrium precipitation model

Briggs (1996) first accepted an intermediate value of $\mathrm{K}_{\mathrm{sp}}=20.3$, but later changed this to $\mathrm{K}_{\mathrm{sp}}=22.2$ in order to obtain orthoP residuals of the right order, according to published precipitation data. From calibration to Mid-Halton Works results, a revised value of $\mathrm{K}_{\mathrm{sp}}=$ 22.0 was accepted by Briggs (1996). Figure 6 depicts the effect of these changes on $\mathrm{P}_{\text {pres }}$.

It can be seen from Fig. 6 that the precipitation model is extremely sensitive to the $\mathrm{K}_{\mathrm{sp}}$ parameter, with predicted $\mathrm{P}_{\text {pres }}$ values spanning three orders of magnitude over the $\mathrm{pH}$ range 6.8 to 7.8 , which would be applicable to simultaneous precipitation in biological systems. To some degree this weakens confidence in the chemical model and emphasises the importance of calibration of the model to experimental data in as many applications as possible.

\section{Metal hydroxy-phosphate precipitation}

It was previously noted that the Briggs (1996) model contains kinetic expressions for the dissociation of metal (hydroxy) phosphate butnotforits precipitation. The reason for this is that the precipitation calculations are based on equilibrium chemistry, which is fundamental to Briggs' model. The assumption is made that the precipitation processes take place (virtually) instantaneously at the point (in time and space) of metal salt addition. The kinetic processes are subsequently solved for the steady-state condition.

Metal hydroxide precipitation is modelled as a kinetic process, with a rapid precipitation/ dissociation rate set equal to that for phosphate dissociation. This approach was an attempt to model precipitation kinetics with a rate equation and to assume that the same rate constant $\left(\mathrm{k}_{\mathrm{p}}=\mathrm{k}_{\mathrm{m}}\right)$ would be applicable to the dissociation of metal (hydroxy) phosphate as well as the precipitation and dissociation of metal hydroxide. Briggs (1996) did not report any sensitivity analysis for $\mathrm{k}_{\mathrm{p}}$ or $\mathrm{k}_{\mathrm{m}}$.

The incorporation of both equilibrium and kinetic expressions resulted in a paradox in the model of Briggs (1996): precipitation of metal (hydroxy) phosphate is not modelled as a kinetic process, whereas its dissociation is. It has the implication that metal hydroxy phosphate cannot form dynamically during the solution procedure for predicting the steady-state. This could lead to problems with reaching the correct steady-state result, particularly in modelling BEPR systems where several additional dynamic processes involve $P$ release or uptake.

Using the approach of Briggs (1996), calculation of the initial state would set the mass of phosphate precipitated as metal (hydroxy) phosphate prior to the commencement of the dynamic mathematical

solution procedure. No further formation of this precipitate will be possible since no kinetic process for its formation was included. An initial metal hydroxide precipitate mass would also have been calculated. If the soluble metal concentration (Me) drops below the minimum permissible equilibrium concentration $\left(\mathrm{Me}^{*}\right)$ at any stage during the dynamic calculation (e.g. if the initial Me dose: initial $\mathrm{P}$ concentration $\left(\mathrm{Me}_{0} / \mathrm{P}_{\mathrm{P} 0}\right.$ ratio in Eq. 18$)$ was relatively low - this would be true for many simultaneous dosing situations where a significant degree of biological $P$ removal occurs and chemical addition is for supplementary $\mathrm{P}$ removal), then metal hydroxide dissociation will be "switched on" (Eq. 23) and metal ions will be solubilised. However, it will be impossible for the dynamic solution to predict more metal (hydroxy) phosphate formation as a result. This could lead to the incorrect steady-state prediction for soluble orthoP concentration.

\section{The question of $\mathrm{P}_{\mathrm{p} 0}$}

Related to the above question of the absence of a kinetic expression for metal (hydroxy) phosphate precipitation is that surrounding the definition of $\mathrm{P}_{\mathrm{P} 0}$ (Eqs. 13 and 18). The Briggs (1996) model is based on a conventional aerobic activated sludge system. Therefore, apart from the chemical processes, the only dynamic biological phosphate process that needed to be considered was that of the hydrolysis of organic (complex) phosphate forms to orthoP. Furthermore, since the only point of metal salt addition considered by Briggs was to the last aerobic zone (or the line between this zone and the secondary clarifier), the initial $\mathrm{P}$ concentration at the point of metal addition $\left(\mathrm{P}_{\mathrm{P} 0}\right)$ could be easily calculated. Briggs (1996) did not detail the mathematical solution procedure followed, but presumably a steady-state concentration of $\mathrm{P}_{\mathrm{P} 0}$ was first calculated (i.e. in the absence of metal salt addition) and then used as an initial condition for the algebraic expression in Eq. 18. Again, since Eq. 18 is not a kinetic expression, it would not form part of the dynamic procedure for calculating the steady state.

If the Briggs model is to be extended to BEPR processes, the problem of setting a value for $\mathrm{P}_{\mathrm{P} 0}$ becomes more significant. By definition, BEPR processes are characterised by relatively high steady-state concentrations of phosphate stored in the biomass, with release typically occurring in the anaerobic zone and uptake in the aerobic zones. In such processes, it cannot be assumed that metal salt dosing will necessarily take place in the aerobic zone; the higher soluble orthoP concentrations in the anaerobic zone could increase the efficiency of precipitation (as Eq. 13 predicts). However, 


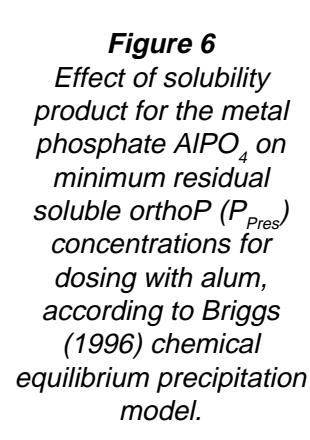

Figure 6

Effect of solubility product for the metal phosphate $\mathrm{AlPO}_{4}$ on minimum residual soluble orthoP $\left(P_{\text {Pres }}\right)$ concentrations for dosing with alum, according to Briggs (1996) chemical model.

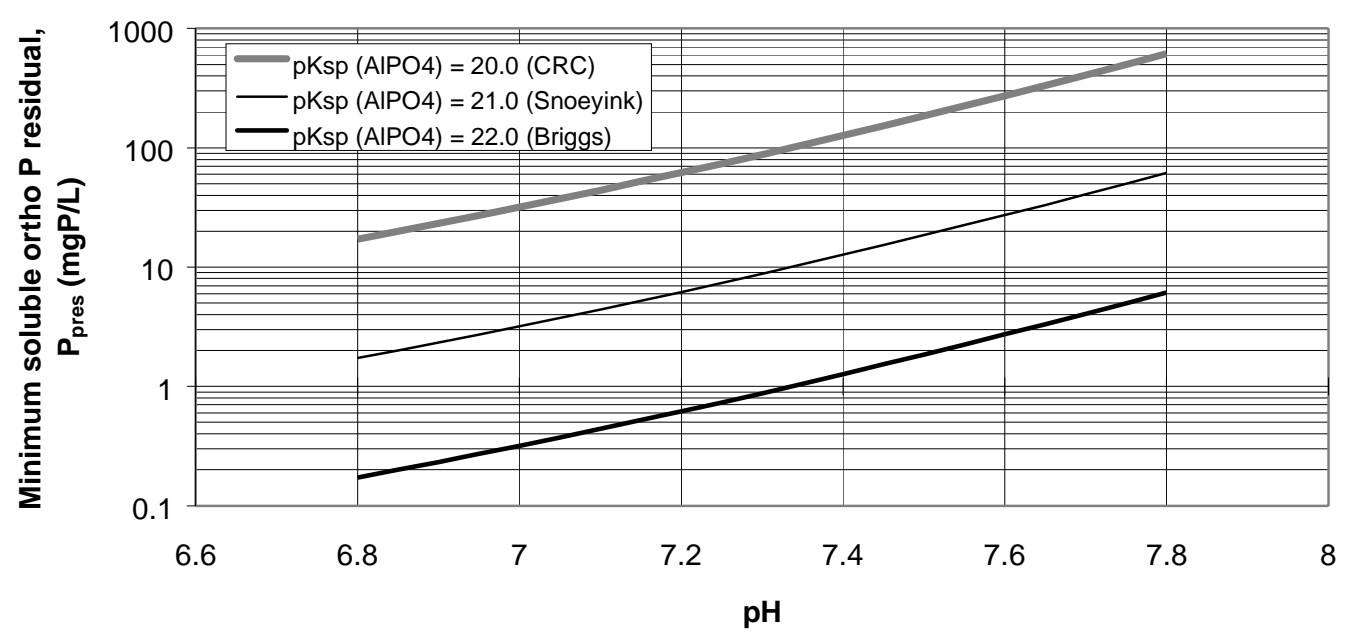

Adsorption and metal complexation

it is also more difficult to predict a steady-state concentration for the anaerobic zone with simultaneous precipitation and BEPR processes both taking place in the system.

To examine the possible effect of uncertainty of $\mathrm{P}_{\mathrm{P} 0}$ at the point of dosing on precipitation, Eq. 13 may be tested, on the assumption that the systems are not equilibrium-limited. The concentration of orthoP removed through precipitation $\left(\mathrm{P}_{\text {prec }}\right)$ can be calculated:

$$
\mathrm{P}_{\text {prec }}=\mathrm{P}_{\mathrm{p} 0}-\mathrm{P}_{\mathrm{P}}^{*}
$$

Figures $7 \mathrm{a} \& \mathrm{~b}$ show the results of applying Eq.13, based upon $\mathrm{P}_{\mathrm{P} 0}$ and $\mathrm{Me}_{0}$ (metal dose) data for the pilot plants in this study (Parts 3 \& 4 - De Haas et al., 2000a \& b).

Assuming $a_{1}=1$ for comparative purposes, it is clear from Fig. 7a that for larger $\mathrm{P}_{\mathrm{P} 0}$ values, uncertainty in $\mathrm{P}_{\mathrm{p} 0}$ exerts a relatively small effect on the $\mathrm{P}_{\text {prec }}$ concentration. For $\mathrm{P}_{\mathrm{P} 0}^{\mathrm{p} 0}$ approximately 25 to $50 \mathrm{mgP} / \ell$ and the constant metal doses examined, uncertainty in $\mathrm{P}_{\text {prec }}$ will be of the order of $1 \mathrm{mgP} / \ell$ (lines almost horizontal) . However, uncertainty in $\mathrm{P}_{\text {prec }}$ increases greatly as $\mathrm{P}_{\mathrm{p}}$ becomes smaller in relation to a constant metal dose (Fig. 7a). In the $\mathrm{P}_{\mathrm{P} 0}$ range $\sim 2$ to $10 \mathrm{mgP} / \ell$ uncertainty over $\mathrm{P}_{\text {prec }}$ lies in the range $\sim 2$ to $5 \mathrm{mgP} / \ell$ for the metal doses examined.

Figure $7 \mathrm{~b}$ shows the effect of using $\mathrm{a}_{1}=1.3$ instead of unity in Eq.13 for ferric ions: above a certain value of $\mathrm{P}_{\mathrm{p} 0}$ the ferric dose is too small to initiate precipitation (refer also Fig. 3). However, at lower $\mathrm{P}_{\mathrm{P} 0}$ the sensitivity of $\mathrm{P}_{\text {prec }}$ to $\mathrm{P}_{\mathrm{P} 0}$ is similar to that with $\mathrm{a}_{1}=1$ (Fig. 7a).

It can be concluded from Fig. 7a that the Briggs (1996) precipitation model may fail to accurately predict effluent orthoP concentrations where the initial orthoP concentration (at the point of chemical dosing) is unknown, and particularly if it falls into the range $<10 \mathrm{mgP} / \ell$. The latter will apply to most real applications where an activated sludge plant receiving domestic wastewater is dosed with chemicals in the aerobic zone. In BEPR plants, if dosing takes place to the anaerobic zone where orthoP concentrations are likely to be $>10 \mathrm{mgP} / \ell$, the uncertainty in $\mathrm{P}_{\mathrm{P} 0}$ will have a smaller impact on the predicted effluent orthoP, but could nevertheless be significant where the objective is to accurately predict removal in relation to a low effluent phosphate standard (e.g. $1 \mathrm{mgP} / \ell$ ). For dosing to the anaerobic zone, the choice of the $a_{1}$ factor in the Briggs model will be more critical (Fig. 7b).
For the systems against which the model was tested, Briggs (1996) concluded that the adsorption component of the chemical model played a negligible part in the predicted $\mathrm{P}$ removal of the system. This suggests that the added complexity introduced as a result of the adsorption processes cannot be justified.

Two further reasons may be given for ignoring the adsorption component of the model proposed by Briggs. Firstly, phosphate adsorption to the biomass has not been taken into account. Secondly, there may be little point in attempting to model phosphate adsorption to metal colloids separately from metal phosphate precipitation when the two mechanisms are likely to be very closely related through ion-exchange or complexation mechanisms. The literature suggests that there is currently insufficient experimental evidence to resolve the exact mechanism by which phosphate is incorporated into an iron hydroxide colloid. The mechanism may be one or more of the following (He et al., 1996):

- adsorption to the colloid;

- co-precipitation with the colloid; or

- co-deposition as iron-phosphate precipitate with the iron hydroxide colloid.

According to He et al. (1996), phosphate adsorption cannot readily be distinguished from ion exchange or surface complexation between phosphate and the iron hydroxide colloid.

Furthermore, from recent work using electron microscopy by He et al. (1996), some iron-P agglomerates in activated sludge appear to be enmeshed by microbial extracellular structures such as fibrils. Most likely, this extracellular organic material includes polysaccharides that appear to contribute significantly to the large capacity for the biomass to complex/bind/adsorb metals (Brown and Lester, 1979). The structural associations between iron hydroxide and microbial cells in activated sludge and secondary effluent are to be the subject of further investigation (He et al., 1996).

In view of the current poor understanding of the exact mechanisms of chemical phosphate removal in activated sludge systems, it seems that the adsorption components of the Briggs (1996) model can be safely ignored. For modelling purposes, any adsorption effects that do occur would be lumped with the precipitation processes. 


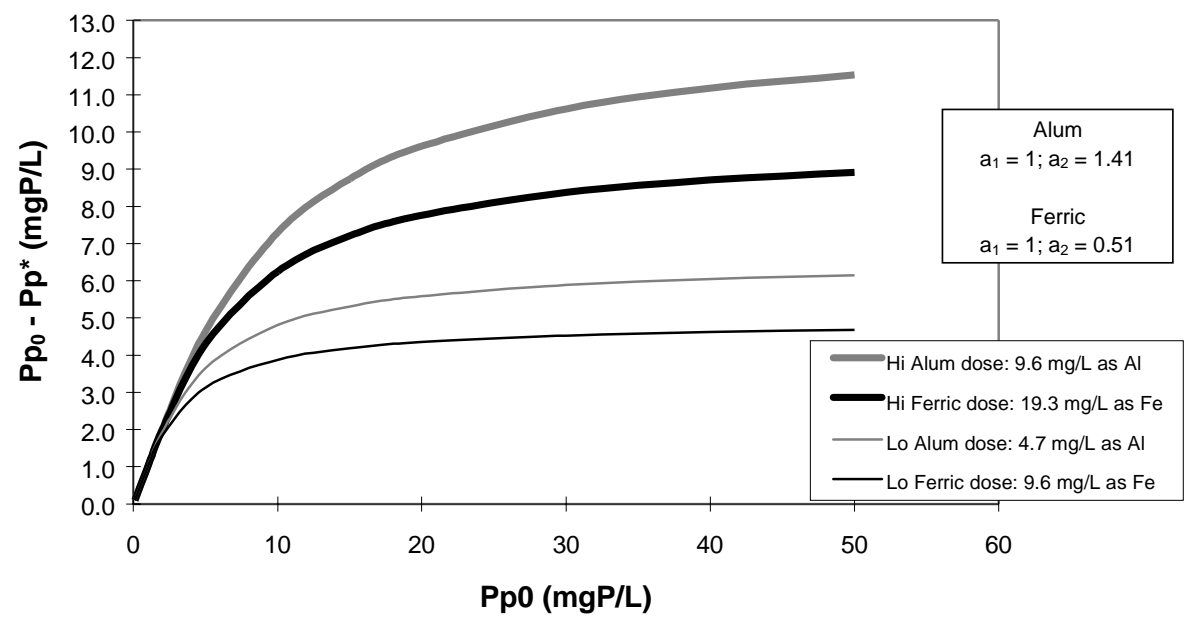

Figure $7 a$

Effect of uncertainty over $P_{p 0}$ on predicted precipitation of ortho $P$

$\left(P_{\text {prec }}=P_{p 0}-P_{P}^{*}\right)$, according to the Briggs chemical model. Refer to Eq. 13 for definitions of $a_{1}$ and $a_{2}$ (ie. $a_{1}$ and $\left.a_{2}\right)$. Alum and ferric chloride doses based on influent flow (refer to pilot-plant data $-D e$ Haas et al., 2000a \& b).

Effect of $\mathrm{P}_{\mathrm{P} 0}$ on chemical precipitation Briggs (1996) model

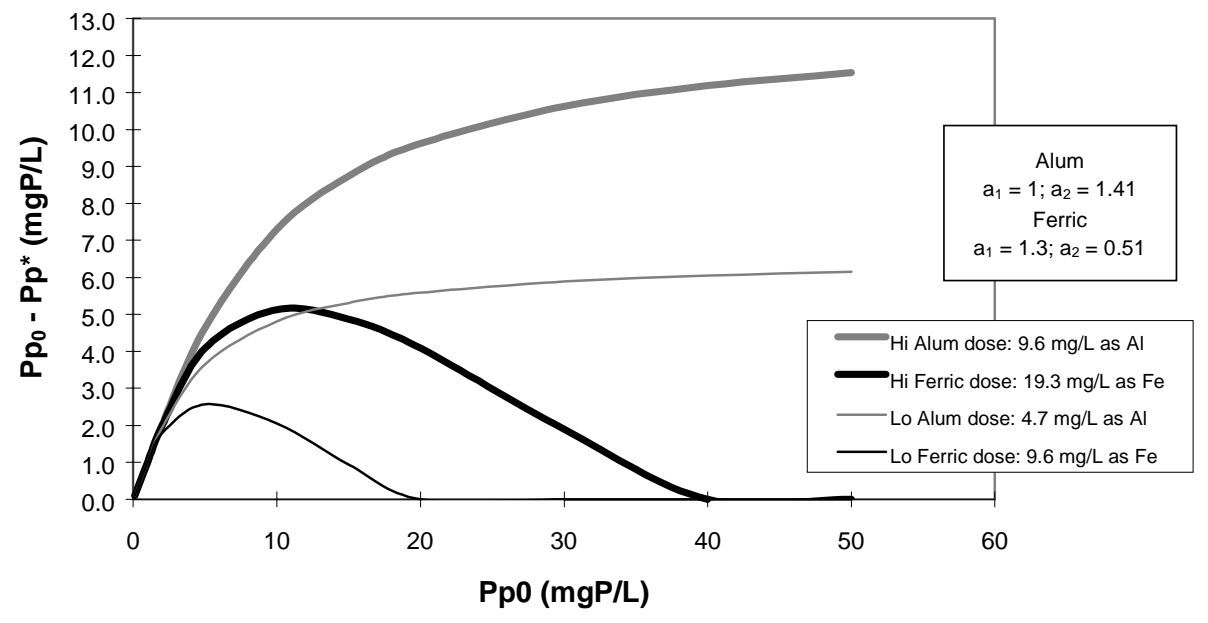

Figure $7 b$

Effect of uncertainty over $P_{p}$ on predicted precipitation of orthoP $\left(P_{\text {prec }}=P_{p 0}-P_{P}^{*}\right)$, according to the Briggs chemical model. Note change for a for ferric chloride. Refer also to Fig. $7 a$

\section{Kinetic models of chemical precipitation}

An alternative to the equilibrium approach to precipitation proposed by Briggs (1996) would be to use a kinetic approach to describe both precipitation and dissociation reactions for metal (hydroxy) phosphate and metal hydroxide. In this case, the rate constants would be lumped parameters incorporating effects due to, inter alia, the stoichiometry and solubility of the precipitate, ion-pairing/ complexation of phosphate and metal ions, metal:P ratio at the dosing point, and adsorption. The number of constants requiring calibration would be greatly reduced in this manner, which would make the model easier to use. Furthermore, the kinetic approach would simplify integration of the chemical model with the biological (including BEPR) processes. However, $\mathrm{pH}$ and alkalinity would also need to be modelled kinetically in order to yield equivalent results to the equilibrium approach, although this would be required only if $\mathrm{pH}$ changes are significant.

The IAWQ Activated Sludge Model (ASM) No. 2 (Henze et al., 1995) uses a simple kinetic approach for inclusion of processes for precipitation using iron (ferric) salts. This model is briefly reviewed below.

\section{IAWQ ASM No. 2}

The IAWQ ASM No.2 (Henze et al., 1995) is an extension of its predecessor (IAWPRC ASM No. 1) by incorporating processes describing biological excess $P$ removal. In addition to the biological processes, ASM2 includes two chemical processes that may be used to model chemical precipitation, namely: precipitation and redissolution. Two components (hypothetical chemical compounds) are added in order to model these processes: metal hydroxide $\left(\mathrm{X}_{\mathrm{MeOH}}\right)$ and metal phosphate $\left(\mathrm{X}_{\mathrm{MeP}}\right)$.

The precipitation model (Henze et al., 1995) is based on the assumption that precipitation and redissolution are reverse processes of each other, which at steady state would be in equilibrium according to:

$$
\mathrm{X}_{\mathrm{MeOH}}+\mathrm{S}_{\mathrm{PO} 4} \ll \mathrm{X}_{\mathrm{MeP}}\left(+\mathrm{H}_{2} \mathrm{O}\right)
$$

Precipitation (PRE) and redissolution (RED) are modelled as simple first order reactions, with the following process rates $\left(\mathrm{r}_{\mathrm{PRE}}\right.$ and $\mathrm{r}_{\mathrm{RED}}$ ) respectively for compound $i$ :

$$
\mathrm{r}_{\mathrm{PRE}, i}=V_{\mathrm{PRE}, i} \cdot \mathrm{k}_{\mathrm{PRE}} \cdot \mathrm{S}_{\mathrm{PO} 4} \cdot \mathrm{X}_{\mathrm{MeOH}}
$$


where:

$V_{\mathrm{PRE}, i}$ and $V_{\mathrm{RED}, i}$ are the respective stoichiometric coefficients for precipitation and redissolution,

$\mathrm{S}_{\mathrm{PO} 4}$ is the concentration of soluble orthoP,

$\mathrm{k}_{\mathrm{PRE}}$ and $\mathrm{k}_{\mathrm{RED}}$ are the respective kinetic constants for the precipitation and redissolution reactions, and

$\mathrm{X}_{\mathrm{MeOH}}$ and $\mathrm{X}_{\mathrm{MeP}}$ are the respective concentrations of metal hydroxide and metal phosphate in the mixed liquor.

According to Aspegren (1995), these expressions originated from Langmuir-type expressions for phosphorus precipitation in soil and a switching function for $\mathrm{S}_{\mathrm{PO} 4}$ may be included $\left(\mathrm{S}_{\mathrm{PO} 4} /\left[\mathrm{K}_{\mathrm{PO} 4}\right.\right.$ $\left.+\mathrm{S}_{\mathrm{PO} 4}\right]$ ), where $\mathrm{K}_{\mathrm{PO} 4}$ is very small (e.g. $0.001 \mathrm{mgP} / \ell$ ).

Henze et al. (1995) presented the example of dosing ferric ions to an activated sludge system. In this case, $\mathrm{MeOH}$ is assumed to be $\mathrm{Fe}(\mathrm{OH})_{3}$ and $\mathrm{MeP}$ is assumed to be $\mathrm{FePO}_{4}$. Provision may be made in the model for loss of hydroxide ions (decrease in alkalinity) from the bulk phase during formation of $\mathrm{Fe}(\mathrm{OH})_{3}$ but $\mathrm{pH}$ is assumed to be near neutrality. [The assumption of constant $\mathrm{pH}$ is currently a constraint of the ASM2 model. The charge balance calculation for alkalinity is based on a $\mathrm{pH}$ value of 6.86 at which all the alkalinity is (effectively) in the form of bicarbonate $\left(\mathrm{HCO}_{3}^{-}\right)$. In practical application, where uncertainty over $\mathrm{pH}$ exists, a low calculated alkalinity value should be considered as a warning of possible low pH conditions (IAWQ, 1995)].

Effectively, in ASM No.2 $\mathrm{Fe}^{3+}$ dosing is modelled as the addition of $\mathrm{Fe}(\mathrm{OH})_{3}$ in the form of an influent to the activated sludge plant, on the basis that $1 \mathrm{~g} \mathrm{Fe}$ converts to $1.91 \mathrm{~g} \mathrm{Fe}(\mathrm{OH})_{3}$. If total suspended solids (TSS) is modelled, the $\mathrm{Fe}(\mathrm{OH})_{3}$ is considered to contribute to the influent TSS. Absolute values for the stoichiometry of orthoP precipitation may be calculated as follows:

$$
\mathrm{PO}_{4}^{3-}+\mathrm{Fe}(\mathrm{OH})_{3} \ll \mathrm{FePO}_{4}+3 \mathrm{OH}^{-}
$$

where $1 \mathrm{~g}$ P reacts with $3.45 \mathrm{~g} \mathrm{Fe}(\mathrm{OH})_{3}$ to form $4.87 \mathrm{~g} \mathrm{FePO}_{4}$. Hence, with the units of $\mathrm{P}$ concentration being $\mathrm{g} / \mathrm{m}^{3}$ (or $\mathrm{mgP} / \ell$ ), for dosing with ferric ions:

$$
\begin{array}{ll}
V_{\text {PRE, MeOH }} & =-3.45 \\
V_{\text {RED, MeOH }} & =3.45 \\
V_{\text {PRE, MeP }} & 4.87 \\
V_{\text {RED, MeP }} & =-4.87
\end{array}
$$

Similarly, for alum dosing:

$$
\mathrm{PO}_{4}^{3-}+\mathrm{Al}(\mathrm{OH})_{3} \ll \mathrm{AlPO}_{4}+3 \mathrm{OH}^{-}
$$

where $1 \mathrm{~g} \mathrm{P}$ reacts with $2.52 \mathrm{~g} \mathrm{Al}(\mathrm{OH})_{3}$ to form $3.94 \mathrm{~g} \mathrm{AlPO}_{4}$. Hence, with the units of $\mathrm{P}$ concentration being $\mathrm{g} / \mathrm{m}^{3}$ (or $\mathrm{mgP} / \ell$ ), for dosing with aluminium ions:

$$
\begin{array}{ll}
V_{\mathrm{PRE}, \mathrm{MeOH}} & =-2.52 \\
V_{\mathrm{RED}, \mathrm{MeOH}} & =2.52 \\
V_{\mathrm{PRE}, \mathrm{MeP}} & =3.94 \\
V_{\mathrm{RED}, \mathrm{MeP}} & =-3.94
\end{array}
$$

Henze et al. (1995) proposed values for the kinetic constants on the basis that these values gave predictions of residual orthoP concentrations that are considered typical of simultaneous precipitation with $\mathrm{FeCl}_{3}$ in activated sludge systems:

$$
\begin{aligned}
& \mathrm{k}_{\text {PRE }}=11 \cdot\left(\mathrm{mgFe}(\mathrm{OH})_{3}\right)^{-1} \cdot \mathrm{d}^{-1} \\
& \mathrm{k}_{\mathrm{RED}}=0.6 \mathrm{~d}^{-1}
\end{aligned}
$$

Henze et al. (1995) did not indicate whether these kinetic constants would also be suitable for alum-dosed systems.

\section{Conclusions}

A model based partly on equilibrium and partly on kinetic processes has been proposed for simultaneous precipitation of phosphate in activated sludge systems (Briggs, 1996). The equilibrium chemistry incorporated in this model gives it a fundamental basis for the incorporation of $\mathrm{pH}$ and alkalinity as model parameters. However, the integration of equilibrium and kinetic processes poses potential problems in deriving a solution for this model. Moreover, like any other model, it is highly dependent on calibration. The Briggs (1996) model proved to be sensitive to several key constants (notably the solubility products of the precipitates and one or more of the equilibrium constants for metal-phosphate ion pairs). Calibration of the model to particular applications will require manipulation of these constants. To some extent, this negates the value of the model and should be seen in the light of the considerable complexity introduced by the equilibrium chemistry expressions. This suggests that the approach taken by the IAWQ Task Team in ASM No. 2 (Henze et al., 1995) is more practical, mainly in that it is much simpler and may require empirical calibration of only two rate constants.

In view of the above, for the purposes of this study, the results of pilot plant experiments presented in Parts 3, 4 and 5 (De Haas et al., 2000 a, b; 2001) were tested against the IAWQ ASM No. 2 model.

\section{Acknowledgement}

The help of Prof. Dick Loewenthal in reviewing the equilibrium chemistry aspects of this paper is gratefully acknowledged.

\section{References}

ASPEGREN H (1995) Evaluation of a High Loaded Activated Sludge Process for Biological Phosphorus Removal. Ph.D. Thesis, Dept. of Water and Environ. Eng., Lund Univ. of Technol., Lund, Sweden.

BARKER PS and DOLD PL (1997) General model for biological nutrient removal activated sludge systems: Model presentation. Water Environ. Res. 69 (5) 969-984.

BRIGGS TA (1996) Dynamic Modelling of Chemical Phosphorus Removal in the Activated Sludge Process. M. Eng. Thesis, School of Graduate Studies, McMaster Univ., Hamilton, Ontario, Canada.

BROWN MJ and LESTER JN (1979) Metal removal in activated sludge: The role of bacterial extracellular polymers. Water Res. 13 817-837.

CRC (1988) CRC Handbook of Chemistry and Physics ( $1^{\text {st }}$ Student Edn.) Weast RC (ed.), CRC Press.

DE HAAS DW, WENTZEL MC and EKAMA GA (2000a) The use of simultaneous chemical precipitation in modified activated sludge systems exhibiting biological enhanced phosphate removal. Part 3: Experimental periods using alum. Water SA 26 (4) 467-484.

DE HAAS DW, WENTZEL MC and EKAMA GA (2000b) The use of simultaneous chemical precipitation in modified activated sludge systems exhibiting biological enhanced phosphate removal. Part 4: Experimental periods using ferric chloride. Water SA 26 (4) 485-504.

DE HAAS DW, WENTZEL MC and EKAMA GA (2001) The use of simultaneous chemical precipitation in modified activated sludge systems exhibiting biological enhanced phosphate removal. Part 5: Experimental periods using a ferrous-ferric chloride blend. Water SA 27 (2) 117-134.

DOLD PL and BRIGGS TA (1995) Simultaneous chemical phosphorus removal: Modelling and case studies. Proc. of the Water Environment Fed. $68^{\text {th }}$ Annu. Conf. and Exhib., Miami Beach, Florida, USA (21-25 October) Vol. I, 523-534. 
DOLD PL, WENTZEL MC, BILLING AE, EKAMA GA and MARAIS GvR (1991) Activated Sludge System Simulation Programs. Water Research Commission, PO Box 824, Pretoria, South Africa.

GALARNEAU E and GEHR R (1997) Phosphorus removal from wastewaters: Experimental and theoretical support for alternate mechanisms. Water Res. 31 (2) 328 - 338.

HE QH, LEPPARD G, PAIGE CR and SNODGRASS WJ (1996) Transmission electron microscopy of a phosphate effect on the colloid structure of iron hydroxide. Water Res. 30 (6) 1345-1352.

HENZE M, GRADY CPL (Jr), GUJER W, MARAIS GvR and MATSUO T (1987) Activated Sludge Model No. 1. IAWPRC Sci. and Techn. Report No. 1, IAWPRC, Queen Anne's Gate, London.

HENZE M, GUJER W, MINO T, MATSUO T, WENTZEL MC and MARAIS GvR (1995) Activated Sludge Model No. 2. IAWQ Task Group on Mathematical Modelling for Design and Operation of Biological Nutrient Wastewater Treatment Processes. Int. Assoc. on Water Quality, 1 Queen Anne's Gate, London.

LOEWENTHAL RE and MARAIS GvR (1976) Carbonate Chemistry of Aquatic Systems, Vol. I: Theory and Application. Ann Arbor Science, Ann Arbor, Michigan.

LUEDECKE C, HERMANOWICZ SH and JENKINS D (1989) Precipitation of ferric phosphate in activated sludge: A chemical model and its verification. Water Sci. Technol. 21 (Brighton) 325-327.

NARASIAH KS, MORASSE C and LEMAY J (1991) Nutrient removal from aerated lagoons using alum and ferric chloride. Water Sci. Technol. 23 (Kyoto) 1563.
RABINOWITZ B and MARAIS GvR (1980) Chemical and Biological Phosphorus Removal in the Activated Sludge ${ }^{\mathrm{P}}$ rocess. Research Report No. W32, Univ. of Cape Town, Dept. of Civil Eng., March.

SIEBRITZ IP, EKAMA GA and MARAIS GvR (1983) Biological Excess Phosphorus Removal in the Activated Sludge Process. Research Report No. W47, Dept. of Civil Eng., Univ. of Cape Town, South Africa.

SNOEYINK VL and JENKINS D (1980) Water Chemistry. John Wiley, Toronto.

STANDARD METHODS (1985) Standard Methods for the Examination of Water and Wastewater (16th edn.) American Public Health Association, Washington DC.

THORNBERG D (1995) Improved design and operation with a dynamic activated sludge model. Paper presented at Conf. on New and Emerging Environ. Technol. and Products for Wastewater Treatment and Stormwater Collection. Sheraton Centre, Toronto, Ontario, Canada. 4-7 June.

WENTZEL MC and EKAMA GA (1995) Modelling of biological nutrient removal activated sludge systems - An overview. Proc. Bio-PHannover 95 Int. Conf., Inst. für Siedlungswasserwirtschaft und Adfalltechnik, Univ. of Hannover, Hannover, Germany. 14-1 - 14-31.

WENTZEL MC, EKAMA GA and MARAIS GvR (1992) Processes and modelling of nitrification denitrification biological excess phosphorus removal systems - A review. Water Sci. Technol. 25 (6) 59-82.

\section{Appendix A}

\section{Data set for equilibrium constants of aluminium ion pairs accepted by Briggs (1996)}

Briggs (1996) identified the following aluminium hydroxide ion pairs (refer to Table 1):

$$
\begin{array}{ll}
\mathrm{Me}^{3+}+\mathrm{H}_{2} \mathrm{O} \circledast \mathrm{Me}(\mathrm{OH})^{2+}+\mathrm{H}^{+} & \mathrm{k}_{\mathrm{Me}, 1}=5.0 \\
\mathrm{Me}^{3+}+2 \mathrm{H}_{2} \mathrm{O} \circledast \mathrm{Me}(\mathrm{OH})_{2}^{+}+2 \mathrm{H}^{+} & \mathrm{k}_{\mathrm{Me}, 2}=8.7 \\
\mathrm{Me}^{3+}+3 \mathrm{H}_{2} \mathrm{O} \circledast \mathrm{Me}(\mathrm{OH})_{3}^{0}+3 \mathrm{H}^{+} & \mathrm{k}_{\mathrm{Me}, 3}=15.2 \\
\mathrm{Me}^{3+}+4 \mathrm{H}_{2} \mathrm{O}{ }_{\circledR} \mathrm{Me}(\mathrm{OH})_{4}{ }^{-}+4 \mathrm{H}^{+} & \mathrm{k}_{\mathrm{Me}, 4}=23.3
\end{array}
$$

Alternatively, the ion pairs can be written as acid-base reactions in the following manner:

$$
\begin{aligned}
& \mathrm{Me}^{3+}+\mathrm{H}_{2} \mathrm{O} \circledast \mathrm{Me}(\mathrm{OH})^{2+}+\mathrm{H}^{+} \quad \mathrm{k}_{\mathrm{a}, 1} \\
& \mathrm{Me}(\mathrm{OH})^{2+}+\mathrm{H}_{2} \mathrm{O}{ }^{\circledR} \mathrm{Me}(\mathrm{OH})_{2}^{+}+\mathrm{H}^{+} \quad \mathrm{k}_{\mathrm{a}, 2} \\
& \mathrm{Me}(\mathrm{OH})_{2}{ }^{+}+\mathrm{H}_{2} \mathrm{O} \circledast \mathrm{Me}(\mathrm{OH})_{3}{ }^{0}+\mathrm{H}^{+} \quad \mathrm{k}_{\mathrm{a}, 3} \\
& \mathrm{Me}(\mathrm{OH})_{3}^{0}+\mathrm{H}_{2} \mathrm{O}{ }_{8} \mathrm{Me}(\mathrm{OH})_{4}^{-}+\mathrm{H}^{+} \quad \mathrm{k}_{\mathrm{a}, 4}
\end{aligned}
$$

The values of the equilibrium constants $\mathrm{k}_{\mathrm{a}, 1}$ through $\mathrm{k}_{\mathrm{a}, 4}$ can be derived from $\mathrm{k}_{\mathrm{Me}, 1}$ through $\mathrm{k}_{\mathrm{Me}, 4}$. For example, using the above data for the aluminium ion pairs:

$$
\begin{aligned}
& \mathrm{k}_{\mathrm{a}, 1}=\mathrm{k}_{\mathrm{Me}, 1}=10^{-5.0} \\
& \mathrm{k}_{\mathrm{Me}, 1}=\frac{\left[\mathrm{Me}(\mathrm{OH})^{2+}\right] \cdot\left[\mathrm{H}^{+}\right]}{\left[\mathrm{Me}^{3+}\right]}
\end{aligned}
$$

therefore:

$$
\left[\mathrm{Me}^{3+}\right]=\frac{\left[\mathrm{Me}(\mathrm{OH})^{2+}\right] \cdot\left[\mathrm{H}^{+}\right]}{\mathrm{k}_{\mathrm{Me}, 1}}
$$

$$
\mathrm{k}_{\mathrm{Me}, 2}=\frac{\left[\mathrm{Me}(\mathrm{OH})_{2}^{+}\right] \cdot\left[\mathrm{H}^{+}\right]^{2}}{\left[\mathrm{Me}^{3+}\right]}
$$

therefore:

$$
\frac{\mathrm{k}_{\mathrm{Me}, 2}}{\mathrm{k}_{\mathrm{Me}, 1}}=\frac{\left[\mathrm{Me}(\mathrm{OH})_{2}^{+}\right] \cdot\left[\mathrm{H}^{+}\right]}{\left[\mathrm{Me}(\mathrm{OH})^{2+}\right]}=\mathrm{k}_{\mathrm{a}, 2}=10^{-8.7+5.0}=10^{-3.7}
$$

Similarly, it can be shown that :

$$
\frac{\mathrm{k}_{\mathrm{Me}, 3}}{\mathrm{k}_{\mathrm{Me}, 2}}=\frac{\left[\mathrm{Me}(\mathrm{OH})_{3}{ }^{0}\right] \cdot\left[\mathrm{H}^{+}\right]}{\left[\mathrm{Me}(\mathrm{OH})_{2}^{+}\right]}=\mathrm{k}_{\mathrm{a}, 3}=10^{-15.2+8.7}=10^{-6.5}
$$

and:

$$
\frac{\mathrm{k}_{\mathrm{Me}, 4}}{\mathrm{k}_{\mathrm{Me}, 3}}=\frac{\left[\mathrm{Me}(\mathrm{OH})_{4}^{-}\right] \cdot\left[\mathrm{H}^{+}\right]}{\left[\mathrm{Me}(\mathrm{OH})_{3}{ }^{0}\right]}=\mathrm{k}_{\mathrm{a}, 4}=10^{-23.3+15.2}=10^{-8.1}
$$

It can be expected that the series $\mathrm{pK}_{\mathrm{a}, 1}<\mathrm{pK}_{\mathrm{a}, 2}<\mathrm{pK}_{\mathrm{a}, 3}<\mathrm{pK}_{\mathrm{a}, 4}$ will emerge with the increasing substitution of $\mathrm{Me}^{3+}$ ions with $\mathrm{OH}^{-}$. However, from the above, it can be seen that the data of Briggs (1996) for the aluminium ion pairs produces an inconsistency in that $\mathrm{pK}_{\mathrm{a}, 2}=3.7<\mathrm{pK}_{\mathrm{a}, 1}=5.0$. The data for the iron ion pairs (Table 1) does not show the same problem. The inconsistency in the aluminium ion pair equilibrium constant data may explain why Briggs (1996) found it necessary to manipulate the aluminium hydroxide solubility product in order to provide metal equilibrium residual $\left(\mathrm{Me}_{\mathrm{T}}\right)$ which were in agreement with experimental data reported in the literature. In the $\mathrm{pH}$ range examined here $\mathrm{pH} 6.8$ to 7.8), $\mathrm{Me}_{\mathrm{T}}$ for aluminium is particularly sensitive to the choice of $\mathrm{k}_{\mathrm{Me}, 3}$. This aspect needs further investigation. 